\title{
The TOMO-ETNA experiment: an imaging active campaign at Mt. Etna volcano. Context, main objectives, working-plans and involved research projects
}

Jesús M. Ibáñez ${ }^{1,2,{ }^{\star}}$, Janire Prudencio ${ }^{1,3}$, Alejandro Díaz-Moreno ${ }^{1,4}$, Domenico Patanè ${ }^{2}$, Giuseppe Puglisi ${ }^{2}$, Birger-Gottfried Lühr ${ }^{5}$, Francisco Carrión ${ }^{1}$, Juan José Dañobeitia ${ }^{6}$, Mauro Coltelli ${ }^{2}$, Francesca Bianco ${ }^{7}$, Edoardo Del Pezzo ${ }^{1,7}$, Torsten Dahm ${ }^{5}$, Veronica Willmott ${ }^{8}$, Valérie Mazauric ${ }^{9}$

${ }^{1}$ Instituto Andaluz de Geofisica, Universidad de Granada, Granada, Spain

${ }^{2}$ Istituto Nazionale di Geofisica e Vulcanologia, Sezione di Catania, Osservatorio Etneo, Catania, Italy

${ }^{3}$ University of California, Department of Earth and Planetary Sciences, Berkeley, USA

${ }^{4}$ Universidad de Granada, Departamento de Física Teórica y del Cosmos, Granada, Spain

${ }^{5}$ Helmholtz-Zentrum Potsdam, Deutsches GeoForschungsZentrum GFZ, Potsdam, Germany

${ }^{6}$ Centro Mediterráneo de Investigaciones Marinas y Ambientales, ICM, Consejo Superior de Investigaciones Cientificas, Barcelona, Spain

${ }^{7}$ Istituto Nazionale di Geofisica e Vulcanologia, Sezione di Napoli, Osservatorio Vesuviano, Naples, Italy

${ }^{8}$ Alfred-Wegener-Institut, Helmholtz-Zentrum für Polar-und Meeresforschung, International Cooperation, Bremerhaven, Germany

${ }^{9}$ Ifremer, Centre Bretagne, Unité Navires et Systèmes Embarqués (NSE), Plouzané, France

\section{Article history}

Received January 11, 2016; accepted March 9, 2016.

Subject classification:

Active and passive seismic tomography, Etna volcano, MED-SUV, Inner imaging of active volcanoes, Seismology, Volcanology.

\section{ABSTRACT}

The TOMO-ETNA experiment was devised to image of the crust underlying the volcanic edifice and, possibly, its plumbing system by using passive and active refraction/reflection seismic methods. This experiment included activities both on-land and offshore with the main objective of obtaining a new high-resolution seismic tomography to improve the knowledge of the crustal structures existing beneath the Etna volcano and northeast Sicily up to Aeolian Islands. The TOMO-ETNA experiment was divided in two phases. The first phase started on June 15, 2014 and finalized on July 24, 2014, with the withdrawal of two removable seismic networks (a short period network and a broadband network composed by 80 and 20 stations respectively) deployed at Etna volcano and surrounding areas. During this first phase the oceanographic research $\operatorname{vessel}(R / V)$ "Sarmiento de Gamboa" and the hydro-oceanographic vessel $(H / V)$ "Galatea" performed the offshore activities, which includes the deployment of ocean bottom seismometers (OBS), air-gun shooting for wide angle seismic refraction (WAS), multi-channel seismic (MCS) reflection surveys, magnetic surveys and ROV (remotely operated vehicle) dives. This phase finished with the recovery of the short period seismic network. In the second phase the broadband seismic network remained operative until October 28, 2014, and the R/V "Aegaeo" performed additional MCS surveys during November 19-27, 2014. Overall, the information deriving from TOMO-ETNA experiment could provide the answer to many uncertainties that have arisen while exploiting the large amount of data provided by the cutting-edge monitoring systems of Etna volcano and seismogenic area of eastern Sicily.

\section{Introduction}

Mt. Etna is one of the most active volcanoes in the world, located on the densely inhabited eastern coast of Sicily (Italy). It is characterized by almost continuous eruptive activity from its summit craters and fairly frequent lava flow eruptions from fissures opened up on its flanks. At present, knowledge of the deeper structure of Mt. Etna is one of the most intriguing questions that the scientific community working on this volcano would like to image. An improved structural model of this volcano may give new indications on the interaction between its magma plumbing system and regional tectonic regime. Moreover, a joint interpretation in- 
cluding magma driving conditions, structural framework and tectonic forces would provide a new integrated volcanological model, which is at the base of any further studies including volcanic hazard assessment.

Since direct observations inside of a volcano edifice are nearly impossible to obtain, geophysical indirect methods such as gravimetric [e.g. Rymer and Brown 1986; Kauahikaua et al. 2000; Furuya et al. 2003; Battaglia et al. 2008], geodetic [e.g. Dvorak and Dzurisin 1997; Fialko et al. 2001; Dzurisin 2006; Sturkell et al. 2006], magnetic [e.g. Soengkono 1995; Johnston 1997; Michel and Zlonicki 1998; Cassidy et al. 2007] and seismic measurements [e.g. Chiarabba et al. 2004; Alparone et al. 2011; De Barros et al. 2011; O’Brien et al. 2011; Cannata et al. 2013], including seismic attenuation studies [e.g. Del Pezzo et al. 1995, 1996, 2015; Giampiccolo et al. 2007; Del Pezzo 2008; De Gori et al. 2005, 2011; Prudencio et al. 2015a, 2015b, 2015c] must be applied. With these observables, the research community is working to provide a geodynamic and volcanological model that could unify all of them in a single interpretation. Seismological studies of volcanic regions, and mainly seismic tomographies in velocity and attenuation, are one of the most widely applied and promising techniques used to image the inner part structure of volcanic edifices [e.g. Matsuraba et al. 2008; Zandomeneghi et al. 2008; Berger et al. 2011; Paulatto et al. 2012; Koulakov et al. 2013; García-Yeguas et al. 2014].

Nowadays, the relation between the magma source in the mantle and the upper parts of the system, as well as the relation between tectonics and volcanism and the role of lithospheric faults, could be better resolved by performing active seismic experiments. These are several examples, such as those recently have been done at Usu volcano in Japan [Onizawa et al. 2007], at Vesuvius and Stromboli volcanoes [Zollo et al. 1998; Marsella et al. 2007; Castellano et al. 2008], at the Deception volcano, Antarctica [Barclay et al. 2009; Ben Zvi et al. 2009; Zandomeneghi et al. 2009], at Montserrat Island [Shalev et al. 2010; Voight et al. 2014] or more recently at Tenerife Island [Ibáñez et al. 2008; García-Yeguas et al. 2012]. The active seismic experiment is needed to broaden the knowledge of the inner structure of Mt. Etna and surrounding area, from its basement down to the upper mantle.

Mt. Etna volcano and surrounding areas have been the focus of several multidisciplinary studies (see next section) carried out in the last 25 years. They provided detailed information of the most upper part of Mt. Etna volcanic edifice (up to $8 \mathrm{~km}$ below sea level). However it is crucial to enlighten deeper parts of Mt. Etna and surrounding areas with new data, therefore the use of new techniques that could provide high quality and reliable images is essential. Thus the TOMO-ETNA experiment, performed in the framework of EC-FP7 MED-SUV and EUROFLEET2 MEDSUV.ISES projects (Appendix A), was conceived to investigate the inner structure of this volcanic area and its surrounding areas using multidisciplinary approaches. One of the most relevant and innovative aspects of this project is a joint inversion of active and passive seismic data aimed at achieving a snapshot of Mt. Etna volcano and surrounding areas shallow and deep structures. For this purpose, data provided by active and passive seismic sources registered in a large area that covers more than $135 \times 165$ kilometers including terrestrial and marine territories have been collected (Figure 1). The same data set is adequate to perform $2 \mathrm{D}$ and $3 \mathrm{D}$ attenuation tomography, while about $1410 \mathrm{~km}$ of marine seismic reflection profiles were acquired to image in detail the seismic-stratigraphic and structural setting of the crust, to near/down the limit of the Moho discontinuity in the Ionian and Tyrrhenian Seas (Figure 2). Finally, highresolution bathymetry and magnetic surveys together with, ROV (remotely operated vehicle) imaging and sampling will complement the seismic studies. The final goal is to better define the main regional fault systems and the crustal seismo-stratigraphic pattern and to contribute for understanding the physical processes controlling magma ascent beneath Mt. Etna and Aeolian Island volcanoes. This additional information will provide the answer to the many questions that have arisen while exploiting the large amount data set provided by the cutting-edge monitoring systems deployed on Mt. Etna and in eastern Sicily. It is noteworthy that the geodynamic setting of the South Tyrrhenian-Calabrian Arc-Ionian Basin, which originates from the diachronic and fragmented convergence between the Eurasia and Africa plates, is one of the most intriguing worldwide areas. In this framework the relationship between volcanism (i.e. Mt. Etna and Aeolian Islands) and geodynamic setting still presents some shortcomings that the proposed seismic experiment might clarify.

This paper describes the TOMO-ETNA experiment aims, plans, support and funding (Appendix A), timing, involved researchers (Appendix B), international relationships (Appendix $\mathrm{C}$ ) and data management (Appendix D). TOMO-ETNA experiment is involved within the EC-FP7 MED-SUV project which started on June 1st, 2013, and will finish on May 31, 2016, involving 24 partners from European and American scientific institutions, including four research centers, and four European SMEs. The active phase of the experiment started in June 2014 and finished in November 2014. The planning and preparation, prior to the field operations, has foreseen several meetings, during which pro- 


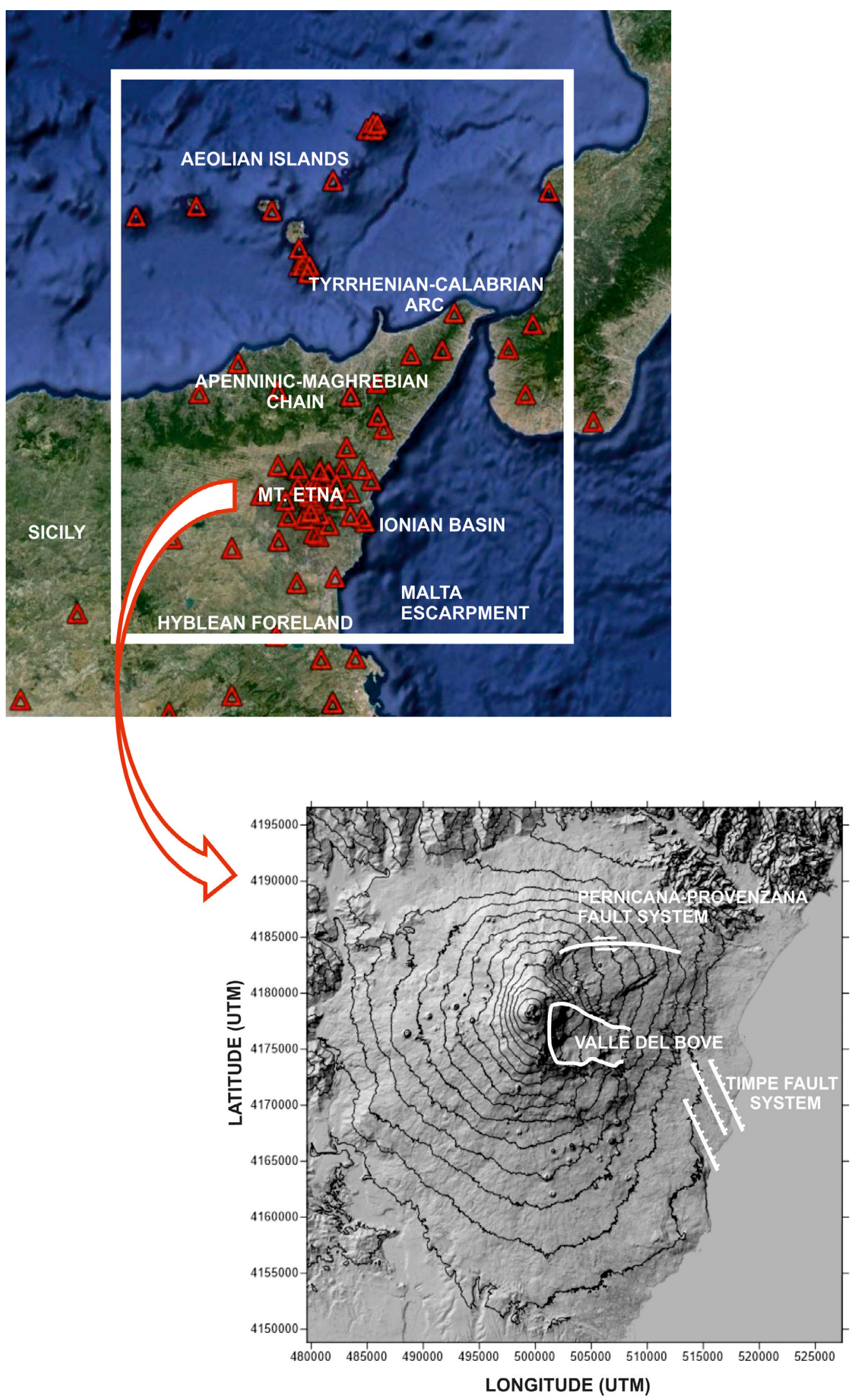

Figure 1. Maps of the area under study in the TOMO-ETNA experiment. Triangles mark the position of the seismic stations of the permanent network of the INGV, Italy. Map was obtained using free Google Earth platform.

posals and new projects were organized in order to obtain additional funds, seismic instruments, oceanographic vessels and the enlargement of the expected research team involved in the experiment. This preliminary phase began in 2011. During the experiment a large number of documents were generated providing detailed information on 
the evolution of the experiment to the general public and to the rest of the consortium. These documents are still available online in the following address http:/ / iagpds. ugr.es/pages/proyecto_italia/proyecto_italia_jesus. MED-SUV applies the concept of the GEO Supersites Initiative to Mt. Etna and Campi Flegrei/Vesuvius volcanoes (southern Italy) optimizing and integrating existing and new observation/monitoring systems, by a breakthrough in understanding of volcanic processes and by increasing the effectiveness of the coordination between science and end-user communities. Specific experiments, such as TOMO-ETNA have been carried out to improve the understanding of internal structure and dynamics of volcanoes. Another fundamental contribution to the achievement of the TOMO-ETNA experiment was provided by the EC-FP7 EUROFLEETS2 project (project MEDSUV.ISES), which provided support to the use of the vessels for carrying out the marine activities. This manuscript is the first of a set of 11 papers describing the multidisciplinary topics of the experiment and some of the preliminary results obtained with the data provided by the experiment.

\section{Context of the experiment}

The eastern side of the Sicily is mainly characterized by two active volcanic areas, Mt. Etna volcano located in eastern Sicily and the Aeolian Archipelago lying in the southeastern Tyrrhenian Sea. Mt. Etna is placed in a geodynamic complex region near the Eurasia-Africa plate boundary. This volcano lies in front of the southeast-verging Apennine-Maghrebian fold-andthrust belt, where the NNW-trending Malta Escarpment separates the Sicilian continental crust from the Ionian Mesozoic oceanic basin, presently subducting beneath the Calabrian Arc [Selvaggi and Chiarabba 1995]. The Aeolian Archipelago represents a volcanic arc consisting of seven major islands and a wider seamount system, result of the Ionian lithosphere subduction beneath the Calabrian Arc and Tyrrhenian Sea [e.g., Caputo et al. 1972; Barberi et al. 1994; Mantovani et al. 1996] and of a post-subduction extensional deformation [Beccaluva et al. 1985; Westaway 1993; Ventura et al. 1999; De Astis et al. 2003].

\subsection{Mt. Etna volcano}

The volcano structure is surrounded by 3 main regional structures: $i$ ) to the north and westwards we find the Apenninic-Maghrebian Chain; ii) southwards appears the Hyblean Foreland that belongs to the African plate [Lentini et al. 2006]; iii) finally to the east stands the Ionian Basin, which is an extensional basin originated during middle-late Mesozoic [Catalano et al. 2001]. This collisional limit induces a regional N-S com- pression that is combined with an E-W extension, related to the Malta Escarpment system [Bousquet and Lanzafame 2004], affecting the eastern part of the volcano. On the other hand, the western part is dominated by the regional compressive regime related to the regional Eurasia-Africa plate collision [Monaco et al. 2005]. The Moho appears to vary considerably from $30 \mathrm{~km}$ underneath the Hyblean Plateau to $18 \mathrm{~km}$ below the Ionian Basin [Nicolich et al. 2000, and reference therein]. According to this regional description, Mt. Etna's location fits neither typical arc magmatism nor a back-arc spreading region associated with the Apennines subduction [Doglioni et al. 2001, Patanè et al. 2011].

Mt. Etna is a complex strato-volcano characterized by an eruptive activity occurring almost continuously, including volatile degassing, strombolian explosions, lava fountains and lava flows. Mt. Etna produces mild explosive eruptions and lava flows from both central craters and lateral fissures, although, a few strong explosive eruptions, up to plinian-type, have been documented [Coltelli et al. 2000]. On the basis of stratigraphic and geochronological studies, several authors have described the spatial and temporal evolution of the volcano as the result of four main volcanic phases [e.g. Gillot et al. 1994; Branca et al. 2004, 2008, 2011; De Beni et al. 2011]. On the east and south-east flanks of the volcano different faults can be recognized; they represent the clearest morphological evidence of a very active tectonic. The Pernicana fault system, located in the north-east flank of the volcano, can be considered the most active fault in the Etnean area, as testified by the slip rate estimations and geodetic measurements. On the eastern flank, near the Ionian coast, seismogenic faults can be related to the NNW-SSE Malta Escarpment that is the main lithospheric structure in the eastern Sicily. Other seismogenetic faults [Patanè et al. 2005], though not recognizable on the surface, can be linked to the NE-SW, ENE-WSW fault systems that control the tectonic evolution of the northern margin of the Hyblean Plateau [Torelli et al. 1998]. Instead on the western sector there is only slight morphological evidence of faulting, such as some short segments of faults observable on the south-western flank (e.g. Ragalna fault). However, the faults with morphological evidence may represent only a part of tectonic structures present in the Etnean area and hidden fault segments could be covered by the huge pile of volcanic products [e.g. Azzaro 1999].

\subsection{The regional structure of the Calabrian-Peloritan} region and Aeolian Arc

The Aeolian Arc is a volcanic structure, about 200 $\mathrm{km}$ long, located on the internal margin of the Calabrian- 
Peloritan forearc region, a Hercynian belt affected by Late Quaternary extensional tectonics and uplift. The Calabro-Peloritan basement runs from northern Calabria to eastern Sicily, and connects the southern Apennine and the Sicily-Maghrebian chains. It is bounded by the Sangineto tectonic line, in the north, and the Tindari-Letojanni-Malta line, in the south. The structure of the Calabro-Peloritano belt consists of a stack of various nappes composed of pre-Alpine metamorphic and granitoid rocks, often with Alpine metamorphic overprint, Mesozoic to Tertiary sedimentary rocks, ophiolitic sequences, and Quaternary sediments.

The Aeolian Arc is formed by seven subaerial volcanic edifices (Alicudi, Filicudi, Salina, Lipari, Vulcano, Panarea and Stromboli), emplaced on a 15 to $20 \mathrm{~km}$ thick continental crust, and their products, which ages between $1.3 \mathrm{Ma}$ and the present, belong to the calc-alkaline, high-K calc-alkaline, shoshonitic and alkaline potassic associations. The geochemical affinity of these rocks and the occurrence of deep seismicity (up to $550 \mathrm{~km}$; Milano et al. [1994]) below the southern Tyrrhenian Sea led to interpret the Aeolian Islands as a volcanic arc related to the active subduction beneath the Calabrian Arc [e.g. Beccaluva et al. 1985; Mantovani et al. 1996].

Structural trends and volcanic activity in the area are strongly controlled by the regional stress fields and bring to identify three distinct sectors:

- the western sector (Alicudi and Filicudi islands) dominated by NW-SE-oriented tectonic lineaments;

- the central sector (Salina, Lipari and Vulcano islands) aligned along the important regional transcurrent fault joining the Aeolian Islands to the Malta Escarpment with a NNW-SSE-oriented trend; on Salina and Lipari subordinate $\mathrm{E}-\mathrm{W}$-oriented trends are also present;

- the eastern sector (Panarea and Stromboli islands) characterized by prevailing NE-SW-oriented tectonic lineaments.

The Aeolian Arc structure has been recently investigated [Chiarabba et al. 2008; Di Stefano et al. 2009] through high resolution $\mathrm{Vp}, \mathrm{Vp} / \mathrm{Vs}$ and Qp passive tomography performed on the base of 15 years of earthquake recordings by Italy's National Seismic Network. Tomography results show two arc-shaped low- and high Vp bands, located respectively at 25 and $100 \mathrm{~km}$ depth. Between 100 and $300 \mathrm{~km}$ two high $\mathrm{Vp}$ zones lie beneath Neapolitan and South Tyrrhenian regions, separated by unperturbed high $\mathrm{Vp}$ mantle. Intermediate depth seismicity is interpreted by the same authors as associated with the subduction of a thin oceanic crust, suggesting the occurrence of vigorous metamorphism. The high Vp/Vs and low Qp anomalies in the overlying mantle is probably associated with melting, this last related to dehydration induced by metamorphism.

\subsection{Deep feeding structures of Etna}

The knowledge of Mt. Etna's plumbing system has been addressed lately from multidisciplinary studies that combine gravimetric, geodetic and seismic techniques, among others [e.g. Battaglia et al. 2008; Bonforte et al. 2013; Carbone et al. 2014; Patanè et al. 2011, 2013; Zuccarello et al. 2013]. Additionally, petrologic studies of magmas give clues of its source. The present plumbing system is quite complex and not very well defined. This system can be described as compose by 3 main structures: i) the deepest part of the reservoir, located at around $10 \mathrm{~km}$ depth b.s.l., was considered the source of the 2001 and part of the 2002-2003 flank eruptions among others [Patanè et al. 2004, 2006, 2011; Corsaro and Pompilio 2004]; ii) the main body of the reservoir spanning 2-9 $\mathrm{km}$ b.s.l. characterized by a long term mixing of the deep ascending magma with the more evolved magmas [Bonforte et al. 2009, 2013; Spilliaert et al. 2006; Corsaro et al. 2013]; iii) a shallow dyke complex, including a small and temporary shallow reservoir that fed the 2011-2014 lava fountaining episodes, which spans on the first 1-4 km below the summit craters [Bonnacorso et al. 2013; Corsaro et al. 2013; Patanè et al. 2013].

\subsection{Tomographic background}

More than thirty years of seismic tomography at Mt. Etna yields a reasonably accurate picture of the shallow-intermediate P-wave velocity structure of the volcano (down to $10 \mathrm{~km}$ depth) with the definition of a main upper and middle crustal intrusion complex. Chiarabba et al. [2004] presented a detailed summary of the seismic tomography preformed at Mt. Etna prior to 2004 (Table 1 from Chiarabba et al. [2004]). According to these authors, the first $3 \mathrm{D}$ tomographic inversion preformed at this volcano was carried out by Hirn et al. [1991] using local earthquakes. They imaged for the first time a high-velocity body (HVB hereinafter) located underneath the volcanic edifice reaching to $6 \mathrm{~km}$ b.s.l. Successive tomographic studies took advantage of the enhancement of the seismic network to improve the seismic dataset and therefore to obtain better resolution images. Cardaci et al. [1993] inverted a 3D Vp model that reached to $20 \mathrm{~km}$ depth using a long term seismic catalog (from 1976 to 1987). De Luca et al. [1997] added to the previous dataset data recorded up to 1995 from temporal and permanent arrays, leading to a new tomographic image. Since the 1990s, advanced tomographic techniques have developed, helping the scientific community to perform more accurate inversions, this is the case of Villaseñor et al. [1998], who took advantage of the previous dataset to apply advanced non-linear procedures, obtaining more accurate 3D seismic velocity models from Mt. Etna volcano. 
Thereafter, researchers focused their efforts in improving the datasets. Chiarabba et al. [2000] and Laigle et al. [2000] increased considerably the number of $\mathrm{P}$ and $\mathrm{S}$ seismic phases to invert. Their results had a much better resolution using fewer earthquakes than the precedent long-term tomographies. Patanè et al. [2002] carried out a high-resolution tomography of the first 4 $\mathrm{km}$ by using $\mathrm{P}$ and $\mathrm{S}$ phase arrivals from almost 300 local events. Low $\mathrm{V}_{\mathrm{p}} / \mathrm{V}_{\mathrm{S}}$ anomaly regions were observed both during the July 2001 and the October 2002 dike intrusions feeding these two eruptions. More recently, Patanè et al. [2006] carried out the first 4D tomography at Mt. Etna, between the 2001 and 2002-2003 eruptive periods, remarking the importance of shortterm (snapshots) tomographies on volcanoes. Their results showed the HVB present in all previous studies and imaged a $\mathrm{Vp} / \mathrm{Vs}$ anomaly for the first time interpreted as the trace of fluid intrusion (magma rich in gas) and gas migration from the shallow magma intrusion in the cracked volume that developed during the eruptive period. By studying the attenuation of P-waves $\left(\mathrm{Q}_{\mathrm{p}}\right)$, De Gori et al. [2005] added new constraints on Mt. Etna’s plumbing system, while Martínez-Arévalo

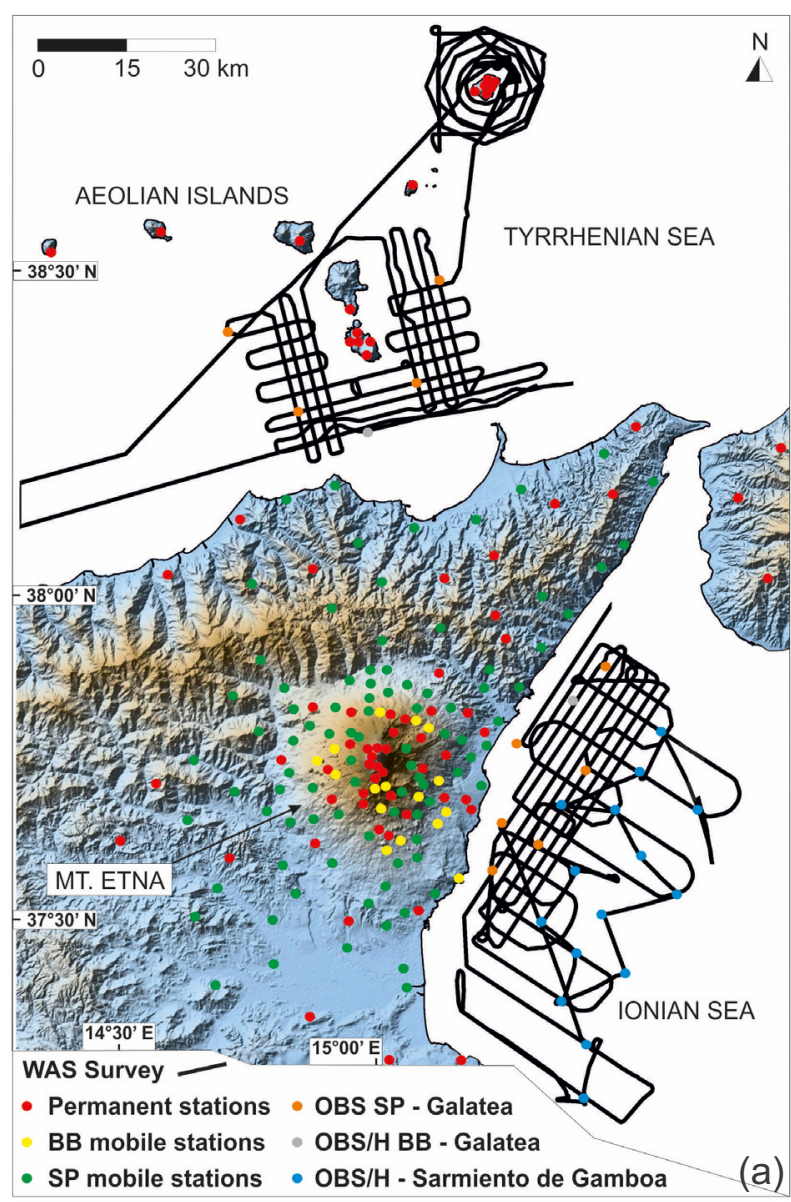

et al. [2005] and De Gori et al. [2011] identified the location and extent of magma bodies at Mt. Etna during the 2001 and 2002-2003 eruptions. The most recent tomographic inversion was performed by Alparone et al. [2012]. These authors combine seismic attenuation and velocity inversion to image the deep structure of Mt. Etna. The most important result obtained from this joint analysis of $\mathrm{V}_{\mathrm{P}}, \mathrm{V}_{\mathrm{P}} / \mathrm{V}_{\mathrm{S}}$ and $\mathrm{P}$-wave attenuation is an anomalous zone with normal to high $\mathrm{V}_{\mathrm{P}}$ and low $\mathrm{V}_{\mathrm{P}} / \mathrm{V}_{\mathrm{S}}$, which partially overlaps with a low $\mathrm{Q}_{\mathrm{p}}$ volume located along a NS trending "channel" beneath the central crater. This can be interpreted as a shallow volume characterized by high temperature where the magma is located with the presence of supercritical fluids.

\subsection{The permanent seismic network of the INGV}

The success of the above seismic studies at Mt. Etna has been facilitated thanks to the existence of a dense and high quality permanent seismic network operated by Italy's Istituto Nazionale di Geofisica e Vulcanologia (INGV) [e.g., Patanè et al. 1999, 2004, 2013]. This network consists of 44 seismic stations, 32 of which are equipped with broadband (BB) and 12 with

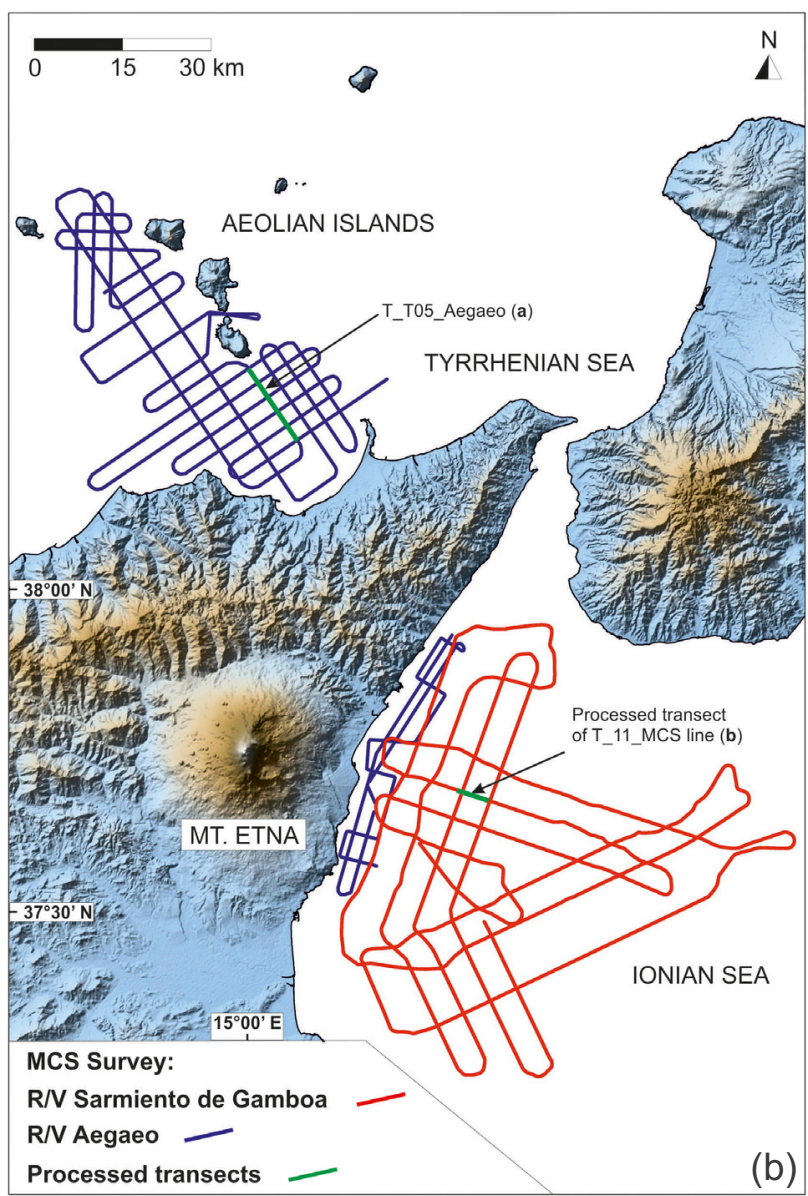

Figure 2. Lines of shots: (a) wide angle seismic (WAS) for the "Sarmiento de Gamboa" campaign. Colored dots indicate the position of the seismic stations (see legend in the figure for details); (b) multi-channel seismic (MCS) lines for the "Sarmiento de Gamboa" and "Aegaeo" campaign. (Figure 2 continues on next page.) 

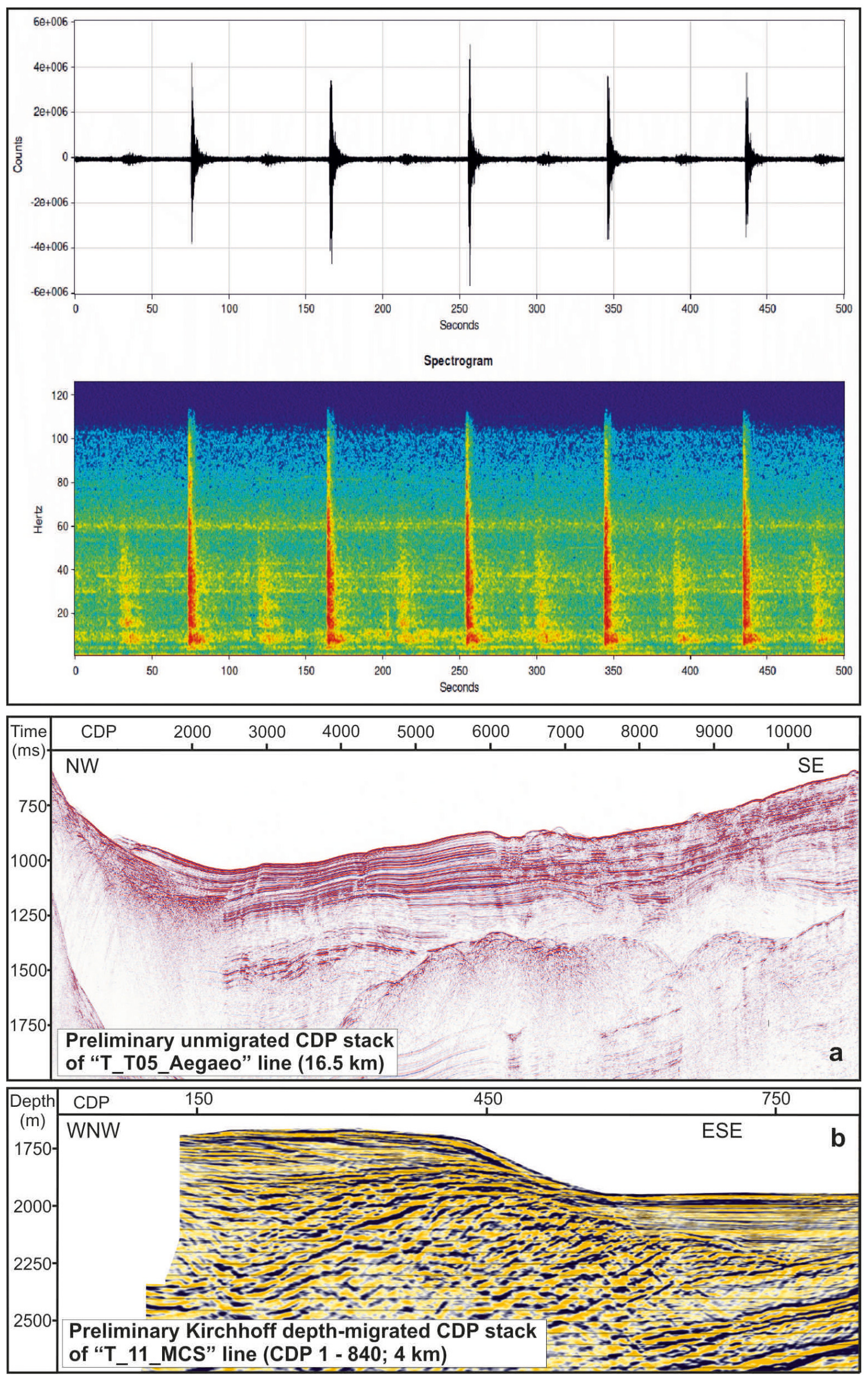

(c)

Figure 2 (continues from previous page). (c) Upper frame: an example of a seismogram and spectrogram of a few shots recorded in an OBS (ocean bottom seismometer) station; bottom frame: preliminary Kirchhoff depth migrated CDP stack of profile T11, shotpoints 400-500. 
short-period (SP) seismometers, ensuring a very good coverage of the volcanic area. Additional $80 \mathrm{BB}$ seismic stations are located in Sicily (see Figure 1). All of BB stations are composed of 3 component Nanometrics Trillium sensors. At the INGV monitoring center in Catania, data are stored with a sampling interval of $0.01 \mathrm{~s}$ over consecutive, $2 \mathrm{~min}$ long digital archives. The seismic network has been considerably enhanced since 2005; the present configuration is described in Patanè et al. [2013]. The seismic stations transmit the data via satellite or radio to the control room of the Osservatorio Etneo (the INGV Etna Observatory).

The TOMO-ETNA experiment will combine the information of this permanent seismic network with the deployment of temporary three components seismic stations of different nature such as short period, broadbands, on land, and ocean bottom seismometers (OBS) offshore. As observed in Figure 2 this experiment has provided a unique opportunity to have a very dense seismic network in this complex and interesting region.

\section{Scientific objectives of the TOMO-ETNA experiment}

The main objective of the TOMO-ETNA experiment is to perform high-resolution seismic tomographies, in velocity and attenuation by using active and passive seismic data, in an area encompassing outstanding volcanoes as Mt. Etna and Aeolian islands. The achievement of this objective is based on the integration of insitu marine and land experiments and observations and on the implementation of new instruments and monitoring systems. For this purpose, onshore and offshore seismic stations, and passive and active seismic events have been used. Additional geophysical data such as seismic reflection, gravimentric and magnetic data have been collected to obtain a joint upper mantle-crust 3D image that could permit to make progress in the understanding of the dynamic of the region.

The core of the study is based on the active seismic experiment that used energy sources at sea. These signals have been recorded by seismic stations deployed on land and on the seafloor (Figure 2) together with the permanent seismic network belonging to the INGV. A temporary dense seismic network composed by 98 seismometers and 25 OBS, both belonging to different institutions, were deployed respectively on land and on sea bottom. Seismic signals were generated by air-guns emplaced on two oceanographic research vessels (hereafter, R/V), "Sarmiento de Gamboa", Spain, and "Aegaeo", Greece. Together with the air-guns shooting processes we acquired data using marine magnetometer in order to complete the information.

The results of this experiment, integrated with previous geophysical surveys (e.g. gravity, magnetotellurics, etc.), will improve the current knowledge of the crust beneath Mt. Etna volcano and the physical processes controlling magma ascent, by cuttingedge modelling. For instance, ground deformation models will improve the knowledge of the physical and geometrical parameters of the internal structure of Mt. Etna and its basement, and will increase the accuracy and robustness of the cut-edge numerical modelling (e.g. finite element or boundary element methods). The obtained new numerical models will benefit from the outcomes of the seismic experiment.

This experiment has a high number of innovative elements, of which we want to highlight:

- Seismic data were recorded by a very large number of seismic stations, that range from ocean bottom seismometers, hydrophones, seismic antennas and permanent and portable seismic stations.

- It represents the first experiment covering such a wide and heterogeneous region, including two volcanic environments and five active volcanoes.

- The seismic tomography will integrate, and for the first time in Mt. Etna and surrounding region, passive sources (earthquakes and LP events) and marine active air-gun shootings. This approach will provide a 3D image inverting simultaneously P-waves travel times for both seismic sources.

- The expected image in the investigated area will be probably the deepest ever obtained in previous research works.

- The final tomographic images will be the product of the integration of seismic data with other geophysical surveys performed both in terrestrial and marine environments as magnetic, gravimetric and magnetotelluric measurements among others.

Aside the main objective, it is planned to achieve also further goals such as:

- characterization of the volcanic processes through cutting-edge data analysis/modelling. This objective is aimed at improving the knowledge on the volcanic subsurface or surface processes during the pre-, syn-, and post-eruptive episodes of Etna and Aeolian volcanoes by fully exploiting the integrate marine and terrestrial data set;

- development of next generation of monitoring and observing systems;

- teaching at high-level (post graduate students) in Geophysics and Volcanic hazards. Some of the personnel involved in the experiment, both onboard and ashore, were Master or $\mathrm{PhD}$ students belonging to different countries involved in the project. The experiment provided a unique opportunity to learn both experimental marine and terrestrial techniques; 
- dissemination. This objective was aimed at broadcasting the outcomes of the project to the scientific community and the general public. This objective included information distribution in different websites, networking with ongoing national and international ventures rooted in the volcanological community, preparation of a TV documentary and others.

It is noteworthy that this project is fully transversal, multidisciplinary and crosses several societal sectors. It is transversal since we apply marine and terrestrial sciences and merge the observations to address multiple scientific problems in order to obtain a unified Earth crust and upper mantle model. It is multidisciplinary due to the combination of different Earth Science disciplines such as Terrestrial and Marine Seismology, Gravimetry, Geomorphology, Magnetic Field and others. Additionally we integrate experiments, technical development and numerical modelling. Several societal sectors will benefit from the outcomes of the project such as Volcanology, Civil Protection, Risk Management and Educational levels.

\section{Work program. General description}

The active high-resolution seismic tomography of Etna volcano has been designed to be performed in several phases, according to the different work involved in them (in next papers of the present special issue a detailed information regarding these field works are provided). They are:

a) preparation of equipment (on-land seismometers, OBS, and other), software and site recognition and detailed planning of the activities;

b) deployment of seismic equipment (OBS and onshore seismic stations);

c) air-guns shooting and other geophysical measurement activities;

d) recovery of the portable marine and onshore seismic stations;

e) data analysis and results.

The experiment included various on- and offshore activities (see Table 1). The on-shore deployment lasted from June 18 - November 24, 2014. Equipment included 80 short period (Table 1) and 18 broadband (BB; Table 1) stations, and included a relocation of 20 of the short period stations (on July 10) to increase the total number of recording sites. Short period equipment was removed on July 20 , while all BB stations remained operative until October 27, in order to record additional natural seismicity. For more information regarding the on seismic network see Ibáñez et al. [2016] in this volume.

Off-shore activities of TOMO-ETNA experiment were completed with the support of four civilian and military vessels. The former were the R/Vs "Sarmiento de Gamboa" (CSIC-UTM, Spain) and "Aegaeo" (HCMR, Greece); the latter were "Galatea" and "Levanzo" (Italian Navy). Off-shore activities began on June 23, with the deployment of 22 OBS in the Ionian Sea and 5 OBS in the Tyrrhenian Sea by the R/V "Sarmiento de Gamboa" and the hydro-oceanographic vessel (hereafter, H/V) "Galatea" (Figure 2). The OBS network included 25 short period and 2 BB stations. All short period OBS were recovered by the R/V "Sarmiento de Gamboa" from July 18-20, while the two BB OBS were recovered on November 25 by the R/V "Aegaeo". For more information regarding the OBS activities see Coltelli et al. [2016] in this volume. From June 27 -July 17, more than 16,000 air-gun shots were fired by the R/V "Sarmiento de Gamboa" during the active-source imaging experiment. Two seismic exploration techniques were employed within this experiment, wide angle seismic (June 27-July 6; WAS) and multi-channel seismic (July 8-17; MCS) surveys (see Table 1 for more details). The "Levanzo" Italian Navy vessel provided support and oversight of the R/V "Sarmiento de Gamboa" during the MCS activities in Ionian Sea (Figure 2). A final round of high resolution MCS survey was performed, using the R/V "Aegaeo", during November 19-26 (see Table 1). For more information regarding MCS surveys see Coltelli et al. [2016] and Firetto Carlino et al. [2016] in this volume.

In Figure 2c, we show about $16.5 \mathrm{~km}$ of profile TT05 acquired in the Tyrrhenian Sea and about $4 \mathrm{~km}$ of profile T-11 acquired in the Ionian Sea (see location in Figure 2b) after a preliminary CDP stack and post-stack depth migration, with the aim of providing a glimpse of the overall data quality. CDP data processing included geometry installation, and spiking/predictive deconvolution followed by band-pass filtering. Semblance-based velocity analysis methods were used to define a $2 \mathrm{D}$ background stacking velocity model for CDP ensemble stack. The stacking velocity model was then smoothed and converted to interval velocity to provide an interval velocity model for post-stack Kirchhoff depth migration.

Finally, with the aim of better defining major geological and structural features of the area, the H/V "Galatea" performed additional scientific activities, such as magnetic surveys (for more information regarding the employed equipment, see Table 1) and ROV dives between June 26 and July 5 . New high resolution shipborne magnetic data were acquired off-shore of Etna volcano, covering the major structural features of both Timpe area and Riposto ridge. The magnetic survey was oriented in the NE-SW direction in order to intersect the major structural-volcanic features off-shore of Etna. Raw magnetic data were processed removing 


\begin{tabular}{|c|c|c|c|c|c|}
\hline \multicolumn{6}{|c|}{ On land activities } \\
\hline \multicolumn{2}{|c|}{ Activity } & Period & Instrumentation & Sensor & Recorder \\
\hline \multirow{2}{*}{\multicolumn{2}{|c|}{ Seismic station deployment }} & \multirow{2}{*}{ June $18-26$} & 80 SP stations & $\begin{array}{l}\text { 3DGeophone PE-6/B } \\
\text { or Mark 3DL4C }\end{array}$ & DSS system \\
\hline & & & $18 \mathrm{BB}$ stations & 120s Trillium & EarthData PR6-24 \\
\hline \multicolumn{2}{|c|}{ Seismic station re-placement } & July 10 & 20 SP stations & 3D Geophone PE-6/B & DSS system \\
\hline \multirow{2}{*}{\multicolumn{2}{|c|}{ Seismic station removal }} & July 19-20 & 80 SP stations & - & - \\
\hline & & October 27-28 & $18 \mathrm{BB}$ stations & - & - \\
\hline \multicolumn{6}{|c|}{ Offshore activities } \\
\hline Activity & Period & Vessel & Instrumentation & Sensor & Details \\
\hline \multirow{3}{*}{ OBS deployment } & \multirow{3}{*}{ June $23-26$} & Sarmiento de Gamboa & 15 SP OBS & - & - \\
\hline & & \multirow{2}{*}{ Galatea } & 10 SP OBS & - & - \\
\hline & & & 2 BB OBS & - & - \\
\hline $\begin{array}{l}\text { Active-source } \\
\text { experiment } 1\end{array}$ & June 27-July 6 & Sarmiento de Gamboa & WAS & $\begin{array}{c}\text { Sercel } \\
8 \text { guns G-GUN II }\end{array}$ & $\begin{array}{l}\text { Total volume: } 5200 \text { c.i. } \\
\text { Pressure: } 2000 \text { p.s.i } \\
\text { Shot every } 90 \mathrm{~s}\end{array}$ \\
\hline $\begin{array}{l}\text { Active-source } \\
\text { experiment } 2\end{array}$ & July 8-17 & $\begin{array}{l}\text { Sarmiento de Gamboa } \\
\text { Levanzo }\end{array}$ & MCS & $\begin{array}{l}\text { SENTINEL Sercel } \\
8 \text { guns G-GUN II }\end{array}$ & $\begin{array}{l}3 \mathrm{~km} \text { long streamer } \\
240 \text { channel streamer } \\
\text { Total volume: } 4340 \text { c.i. } \\
\text { Pressure: } 2000 \text { p.s.i } \\
\text { Shot every } 30 \mathrm{~s}\end{array}$ \\
\hline $\begin{array}{l}\text { Active-source } \\
\text { experiment } 3\end{array}$ & June 26-July 5 & Galatea & $\begin{array}{l}\text { Magnetic survey } \\
\text { ROV }\end{array}$ & Geometrics G880 - & $1340 \mathrm{~km}$ track lines \\
\hline \multirow[t]{2}{*}{$\begin{array}{l}\text { Active-source } \\
\text { experiment } 4\end{array}$} & \multirow[t]{2}{*}{ November $19-26$} & \multirow[t]{2}{*}{ Aegaeo } & MCS & $\begin{array}{l}\text { Sercel } \\
\text { GI-GUN }\end{array}$ & $\begin{array}{l}300 \mathrm{~m} \text { long streamer } \\
96 \text { channel streamer } \\
\text { Total volume: } 840 \mathrm{c} . \mathrm{i} . \\
\text { Shot every } 20 \mathrm{~s}\end{array}$ \\
\hline & & & Gravimetric survey & $\begin{array}{l}\text { LaCoste and Romberg Air-Sea } \\
\text { System II GravityMeter }\end{array}$ & - \\
\hline \multirow{2}{*}{ OBS removal } & July $18-20$ & Sarmiento de Gamboa & 25 SP OBS & - & - \\
\hline & November 25 & Aegaeo & $2 \mathrm{BB}$ OBS & - & - \\
\hline
\end{tabular}

Table 1. Technical details of TOMO-ETNA experiment activities (SP, short period; BB, broadband; OBS, ocean bottom seismometer; WAS, wide angle seismic; MCS, multi-channel seismic; ROV, remotely operated vehicle).

spikes and intervening outlier records, further statistical levelling provided a smooth distribution of the magnetic pattern of survey area. For more information regarding the magnetic and ROV surveys see Coltelli et al. [2016] and Cavallaro et al. [2016] in this volume. For the main technical specifications regarding the scientific equipment employed during the three oceanographic cruises of the TOMO-ETNA experiment see Table 1 and Coltelli et al. [2016].

The $3 \mathrm{D}$ velocity structure of Mt. Etna and surrounding areas will be determined using the data from this large data-set. It is expected to have more than $1 \cdot 10^{7}$ first arrivals recorded both on- and off-shore. The algorithm used for the inversion is an integration of the well-known ATOM-3D and LOTOS [García-Yeguas et al. 2012, 2014] codes in which natural seismicity and active signals will be inverted simultaneously. The first step is to apply an automatic first arrival picking procedure using spectral and temporal characteristics of the signals [Álvarez et al. 2013; García et al. 2016, this volume], including signal recognition algorithms [e.g. Benítez et al. 2007; Gutiérrez et al. 2009; Ibáñez et al. 2009; Cortés et al. 2009, 2014]. The 3D inversion will be performed in three phases: a) general image of the region under study using large lattices and only with the inversion of the active data; $b$ ) inclusion on passive seismicity to better constrain the deeper portion of the region and c) a high resolution seismic tomography of the Etna area using both active and passive seismicity and smaller cells. 


\section{Final remarks}

The TOMO-ETNA experiment is an active source tomographic study, integrated by other geophysical surveys, carried out on the region of one of the most active basaltic volcanoes worldwide that could allow improving the knowledge of Etna. In fact, the future results of the linked researches should help scientists to better understand the eruptive mechanisms, and provide insights on its internal structure and on the deeper part of its plumbing system. This experiment engaged several European and non-European scientific institutions. It required an enormous management effort to plan the fieldworks and to coordinate hundreds of people employed on land and on the vessels during the experiment as well as to organize the data management and processing. It is remarkable that the experiment has been a complete success on the base on: $i$ ) the quantity and high quality of the acquired data; $i$ ) the full integration of permanent and temporal seismic networks in different environments; iii) the wide covered region including volcanic and non-volcanic areas; $i v)$ the multidisciplinary techniques integrated in the data acquisition; $v$ ) the international collaboration and efforts involved in the whole process; $v i)$ the capacity to share responsibilities, data and scientific objectives that will produce at the same time several scientific results, among others.

The large set of acquired data [Barberi et al. 2016, this volume] allowed opening a wide range of multidisciplinary studies, which many of them are being carried out. Beside of the seismic tomography in velocity [Díaz-Moreno et al. 2016, this volume; Ibáñez et al. 2016, this volume], marine seismic reflection studies [Coltelli et al. 2016, this volume; Firetto Carlino et al. 2016, this volume], marine-magnetic surveys and ROV images [Cavallaro et al. 2016, this volume], scattering analysis [Zieger et al. 2016, this volume], 3D seismic array analysis [Zuccarello et al. 2016, this volume] and advance seismic signal processing [García et al. 2016, this volume] are being performed. Contemporaneously this experiment allowed us to increase the knowledge on the effect of geophysical marine measurements on the behavior of cetaceous [Monaco et al. 2016, this volume]. The final goal is to produce a multidisciplinary joint interpretation of the structure of the region generating a more reliable structural model to shed light into the complex framework in which Mt. Etna is placed.

These analyses are only the first step of a long term research program since it is expected to open several research lines such as: $2 \mathrm{D}$ and $3 \mathrm{D}$ seismic attenuation studies, including scattering and intrinsic separation [e.g. Prudencio et al. 2013a, 2013b, 2015b]; precise nonlinear relocation of the seismicity using the new velocity models [e.g. Díaz-Moreno et al. 2015]; identification of seismo-volcanic signals [e.g. Ibáñez et al. 2009; Cortés et al. 2014]; analysis of the wave-field properties [e.g. Palo et al. 2009; De Lauro et al. 2012]; advance LP and explosion source inversion [e.g. La Rocca et al. 2000, 2004; Saccorotti et al. 2004; Petrosino et al. 2011]; analysis of scattered seismic wavefields [e.g. Del Pezzo et al. 1997; De Barros et al. 2012; De Lauro et al. 2012; Zieger et al. 2016, this volume]; analysis of receiver functions [e.g. Martínez-Arévalo et al. 2009; Lodge et al. 2012]; shear waves splitting [e.g. Martínez-Arévalo 2003; Bianco and Zaccarelli 2009, among others]. On the base of previous experience of the involved research team (e.g. Vesuvius and Campi Flegrei, Deception, Tenerife and Stromboli islands) the large amount of high quality geophysical data permit to assume high quality scientific production for the next ten or more years.

Acknowledgements. This paper has been partially funded by the following research projects: the European project MED-SUV funded by the European Union's Seventh Framework Program for research, technological development and demonstration under grant agreement No. 308665; the Spanish COCSABO project (COC-DI2011-08); the European project EUROFLEETS2 (Seventh Framework Programme, grant agreement No. 312762) through transnational access to the research vessels "Sarmiento de Gamboa" operated by CSIC (Spain) and "Aegaeo" by HCMR (Greece); the Geophysical Instrument Pool Potsdam (GIPP) from GFZ (Potsdam) with the project (Seismic TOMOgraphy of ETNA volcano and Eolian Islands, Italy, using active and passive seismic data). We would like to thank the following supporting institutions: Dipartimento Regionale della Protezione Civile, Regione Siciliana; Dipartimento Azienda Regionale Foreste Demaniali, Ufficio Provinciale di Catania; Ente Parco dell'Etna; Unidad de Tecnología Marina - CSIC in Barcelona (Spain); Stato Maggiore Marina (Italian Navy General Staff), CINCNAV (Command in Chief of the Fleet) and Marisicilia (Navy Command of Sicily); Coastal Guard of Messina and Riposto; to obtain support and navigation permissions for the oceanographic cruises: Spanish Foreign Office and Italian Foreign Office. This paper has been partially supported by the Spanish projects TEC2015-68752-R (MINECO/FEDER), KNOWAVES and CGL2015-67130-C2-2. We would like to thank all private and public owners of the sites selected to deploy seismic stations for their kind and unselfish disposal to use their properties. This manuscript has been largely improved by the insightful comments of Dr. Mario Castellano and an anonymous reviewer and by the editor José Morales.

\section{References}

Alparone, S., Barberi, G., Bonforte, A., Maiolino, V., and Ursino, A. (2011). Evidence of multiple strain fields beneath the eastern flank of Mt. Etna volcano (Sicily, Italy) deduced from seismic and geodetic data during 2003-2004, Bulletin of Volcanology, 73(7), 869885.

Alparone, S., Barberi, G., Cocina, O., Giampiccolo, E., Musumeci, C., and Patanè D. (2012). Intrusive mechanism of the 2008-2009 Mt. Etna eruption: Constraints by tomographic images and stress tensor analysis, Journal of Volcanology and Geothermal Research, 229/230, 50-63, doi:10.1016/j.jvolgeores. 
2012.04.001.

Álvarez, I., García, L., Mota, S., Cortés, G., Benítez, C. and De la Torre, A. (2013). An automatic P-Phase picking algorithm base on adaptive multiband processing, Geoscience and Remote Sensing Letters, 10, 1488-1492.

Azzaro, R. (1999). Earthquake surface faulting at Mount Etna volcano (Sicily) and implications for active tectonics, Journal of Geodynamics, 28(2), 193-213.

Barberi, F., Gandino, A., Gioncada, A., La Torre, P., Sbrana, A., and Zenucchini, C. (1994). The deep structure of the Eolian arc (Filicudi-Panarea-Vulcano sector) in light of gravity, magnetic and volcanological data, Journal of Volcanology and Geothermal Research, 61(3), 189-206.

Barberi, G., Giampiccolo, E., Musumeci, C., Scarfi, L., Bruno, V., Cocina, O., Díaz-Moreno, A., Sicali, S., Tusa, G., Tuvè, T., Zuccarello, L., Ibáñez, J.M., and Patanè, D. (2016). Seismic and volcanic activity during 2014 in the region involved by TOMO-ETNA seismic active experiment, Annals of Geophysics, 59(4), S0429, doi:10.4401/ag-7082.

Barclay, A.H., Wilcock, W.S.D., and Ibáñez, J.M. (2009). Bathymetric constraints on the tectonic and volcanic evolution of Deception Island Volcano, South Shetland Islands, Antarctic Science, 21(02), 153-167.

Battaglia, M., Gottsmann, J., Carbone, D., and Fernández, J. (2008). 4D volcano gravimetry. Geophysics, 73(6), WA3-WA18.

Beccaluva, L., Gabbianelli, G., Lucchini, F., Rossi, P.L., and Savelli, C. (1985). Petrology and K/Ar ages of volcanics dredged from the Eolian seamounts: implications for geodynamic evolution of the southern Tyrrhenian basin, Earth and Planetary Science Letters, 74(2), 187-208.

Ben-Zvi, T., Wilcock, W.S., Barclay, A.H., Zandomeneghi, D., Ibáñez, J.M., and Almendros, J. (2009). The P-wave velocity structure of Deception Island, Antarctica, from two-dimensional seismic tomography, Journal of Volcanology and Geothermal Research, 180(1), 67-80.

Benítez, M.C., Ramírez, J., Segura, J.C., Ibáñez, J.M., Almendros, J., García-Yeguas, A., and Cortes, G. (2007). Continuous HMM-based seismic-event classification at Deception Island, Antarctica. Geoscience and Remote Sensing, IEEE Transactions on, 45(1), 138-146.

Berger, P., Got, J.L., González, C.V., and Monteiller, V. (2011). Seismic tomography at Popocatépetl volcano, Mexico, Journal of Volcanology and Geothermal Research, 200(3), 234-244.

Bianco, F., and Zaccarelli, L. (2009). A reappraisal of shear wave splitting parameters from Italian active volcanic areas through a semiautomatic algorithm, Journal of Seismology, 13(2), 253-266.

Bonaccorso, A., Currenti, G., and Del Negro, C. (2013). Interaction of volcano-tectonic fault with magma storage, intrusion and flank instability: A thirty years study at Mt. Etna volcano, Journal of Volcanology and Geothermal Research, 251, 127-136.

Bonforte, A., Gambino, S., and Neri, M. (2009). Intrusion of eccentric dikes: the case of the 2001 eruption and its role in the dynamics of Mt. Etna volcano, Tectonophysics, 471(1), 78-86.

Bonforte, A., Federico, C., Giammanco, S., Guglielmino, F., Liuzzo, M., and Neri, M. (2013). Soil gases and SAR measurements reveal hidden faults on the sliding flank of Mt. Etna (Italy), Journal of Volcanology and Geothermal Research, 251, 27-40.

Bousquet, J., and Lanzafame, G. (2004). The Tectonics and Geodynamics of Mt. Etna: Synthesis and Interpretation of Geological and Geophysical Data, In: A. Bonaccorso, S. Calvari, M. Coltelli, C. Del Negro and S. Falsaperla (eds.), Mt. Etna: Volcano Laboratory, American Geophysical Union, Washington, D.C., doi:10.1029/143GM03.

Branca, S., Coltelli, M., and Groppelli, G. (2004). Geological evolution of Etna volcano, In: A. Bonaccorso, S. Calvari, M. Coltelli, C. Del Negro and S. Falsaperla (eds.), Mt. Etna: Volcano Laboratory, American Geophysical Union, Washington, D.C., doi:10.1029/143GM04.

Branca, S., Coltelli, M., De Beni, E., and Wijbrans, J. (2008). Geological evolution of Mount Etna volcano (Italy) from earliest products until the first central volcanism (between 500 and $100 \mathrm{ka}$ ago) inferred from geochronological and stratigraphic data, International Journal of Earth Sciences, 97(1), 135152.

Branca, S., Coltelli, M., Groppelli, G., and Lentini, F. (2011). Geological map of Etna volcano, 1:50,000 scale, Italian Journal of Geosciences, 130(3), 265291, doi:10.3301/IJG.2011.15

Cannata, A., Di Grazia, G., Aliotta, M., Cassisi, C., Montalto, P., and Patanè, D. (2013). Monitoring seismo-volcanic and infrasonic signals at volcanoes: Mt. Etna case study, Pure and Applied Geophysics, 170(11), 1751-1771.

Caputo, M., Panza, G. F., and Postpischl, D. (1972). New evidences about the deep structure of the Lipari arc, Tectonophysics, 15(3), 219-231.

Carbone, D., Aloisi, M., Vinciguerra, S., and Puglisi, G. (2014). New insight into the relationships between stress , strain and mass change at Mt. Etna during the period between the 1993-94 and 2001 eruptions, Earth Science Reviews, 16, 11012, doi:10.1016/j.ear 
scirev.2014.07.004.

Cardaci, C., Coviello, M., Lombardo, G., Patanè, G., and Scarpa, R. (1993). Seismic tomography of Etna volcano, Journal of Volcanology and Geothermal Research, 56(4), 357-368.

Cassidy, J., France, S.J., and Locke, C.A. (2007). Gravity and magnetic investigation of maar volcanoes, Auckland volcanic field, New Zealand, Journal of Volcanology and Geothermal Research, 159(1), 153-163.

Castellano, M., Augusti, V., De Cesare, W., Favali, P., Frugoni, F., Montuori, C., Sgroi, T., De Gori, P., Govoni, A., Moretti, M., Patanè, D., Cocina, O., Zuccarello, L., Marsella, E., Aiello, G., Di Fiore, V., Ligi, M., Bortoluzzi, G.,Ferrante, V., Marchetti, E., Lacanna, G., and Ulivieri, G. (2008). Seismic Tomography Experiment at Italy's Stromboli Volcano, Eos, Transactions American Geophysical Union, 89(30), 269-270, doi:10.1029/2008EO300001.

Catalano, R., Doglioni, C., and Merlini, S. (2001). On the Mesozoic Ionian Basin, Geophysical Journal International, 144(1), 49-64.

Cavallaro, D., Cocchi, L., Coltelli, M., Muccini, F., Carmisciano, C., Firetto Carlino, M., Ibáñez, J.M., Patanè, D., Filippone, M., and Buttaro, E. (2016). Acquisition procedures, processing methodologies and preliminary results of magnetic and ROV data collected during the TOMO-ETNA experiment, Annals of Geophysics, 59(4), S0431, doi:10.4401/ag-7084.

Chiarabba, C., Amato, A., Boschi, E., and Barberi, F. (2000). Recent seismicity and tomographic modeling of the Mount Etna plumbing system, Journal of Geophysical Research: Solid Earth (1978-2012), 105(B5), 10923-10938.

Chiarabba, C., De Gori, P., and Patanè, D. (2004). The Mt. Etna plumbing system: the contribution of seismic tomography, In: Bonaccorso, A., Calvari, S., Coltelli, M., Del Negro, C., Falsaperla, S. (eds.), Etna volcano laboratory, Geophysical Monograph Series, AGU, 191-204, doi:10.1029/143GM04.

Chiarabba, C., De Gori, P., and Speranza, F. (2008). The southern Tyrrhenian subduction zone: deep geometry, magmatism and Plio-Pleistocene evolution, Earth and Planetary Science Letters, 268(3), 408423.

Coltelli, M., Del Carlo, P., and Vezzoli, L. (2000). Stratigraphic constraints for explosive activity in the past $100 \mathrm{ka}$ at Etna Volcano, Italy, International Journal of Earth Sciences, 89(3), 665-677.

Coltelli, M., et al. (2016). The marine activities performed within the TOMO-ETNA experiment, Annals of Geophysics, 59(4), S0428, doi:10.4401/ag-7081.

Corsaro, R.A., and Pompilio, M. (2004). Magma dynamics in the shallow plumbing system of Mt. Etna as recorded by compositional variations in volcanics of recent summit activity (1995-1999), Journal of Volcanology and Geothermal Research, 137(1), 55-71.

Corsaro, R.A., Di Renzo, V., Distefano, S., Miraglia, L., and Civetta, L. (2013). Relationship between petrologic processes in the plumbing system of Mt. Etna and the dynamics of the eastern flank from 1995 to 2005, Journal of Volcanology and Geothermal Research, 251, 75-89, doi:10.1016/j.jvolgeores.2012. 02.010 .

Cortés, G., Arámbula, R., Gutiérrez, L., Benítez, C., Ibáñez, J., Lesage, P., Álvarez, I., and García, L. (2009). Evaluating robustness of a HMM-based classification system of volcano-seismic events at Colima and Popocatepetl volcanoes, In: Geoscience and Remote Sensing Symposium, 2009 IEEE International, IGARSS 2009 (Vol. 2, pp. II-1012).

Cortés, G., García, L., Álvarez, I., Benítez, C., de la Torre, Á., and Ibáñez, J. (2014). Parallel system architecture (PSA): An efficient approach for automatic recognition of volcano-seismic events, Journal of Volcanology and Geothermal Research, 271, 1-10.

De Astis, G., Ventura, G., and Vilardo, G. (2003). Geodynamic significance of the Aeolian volcanism (Southern Tyrrhenian Sea, Italy) in light of structural, seismological, and geochemical data, Tectonics, 22(4).

De Barros, L., Lokmer, I., Bean, C.J., O’Brien, G.S., Saccorotti, G., Métaxian, J.P., Zuccarello, L., and Patanè, D. (2011). Source mechanism of long-period events recorded by a high-density seismic network during the 2008 eruption on Mount Etna, Journal of Geophysical Research: Solid Earth (1978-2012), 116(B1).

De Barros, L., Martini, F, Bean, C.J, Garcia-Yeguas, A., Ibáñez, J.M. (2012). Imaging magma storage below Teide volcano (Tenerife) using scattered seismic wavefields, Geophysical Journal International, 191, 695-706, doi:10.1111/j.1365-246X.2012.05637.x.

De Beni, E., Branca, S., Coltelli, M., Groppelli, G., and Wijbrans, J.R. (2011). 40Ar/39Ar isotopic dating of Etna volcanic succession, Italian Journal of Geosciences, 130(3), 292-305.

De Gori, P., Chiarabba, C., and Patanè, D. (2005) Qp structure of Mount Etna: Constraints for the physics of the plumbing system, Journal of Geophysical Research: Solid Earth, 1110, B05303, doi:10.1029/2003 JB002875.

De Gori, P., Chiarabba, C., Giampiccolo, E., MartinezArèvalo, C., and Patanè, D. (2011). Body wave attenuation heralds incoming eruptions at Mt. Etna, Geology, 39, 503-506, doi:10.1130/G31993.1.

De Lauro, E., De Martino, S., Palo, M., and Ibáñez, J.M. (2012). Self-sustained oscillations at Volcán de Col- 
ima (Mexico) inferred by Independent Component Analysis, Bulletin of Volcanology, 74, 279-292, doi:10.1007/ s00445-011-0520-x.

De Luca, G., Filippi, L., Patanè, G., Scarpa, R., and Vinciguerra, S. (1997). Three-dimensional velocity structure and seismicity of Mt. Etna volcano, Italy, Journal of Volcanology and Geothermal Research, 79(1), 123-138.

Del Pezzo, E., Ibáñez, J., Morales, J., Akinci, A., and Maresca, R. (1995). Measurements of intrinsic and scattering seismic attenuation in the crust, Bulletin of the Seismological Society of America, 85(5), 1373-1380.

Del Pezzo, E., Simini, M., and Ibáñez, J.M. (1996). Separation of intrinsic and scattering $\mathrm{Q}$ for volcanic areas: a comparison between Etna and Campi Flegrei, Journal of Volcanology and Geothermal Research, 70(3), 213-219.

Del Pezzo, E., La Rocca, M., and Ibáñez, J.M. (1997). Observation of high frequency scattered waves using dense arrays at Teide Volcano, Bulletin of the Seismological Society of America, 87, 1637-1647.

Del Pezzo, E. (2008). Seismic wave scattering in volcanoes, Advances in Geophysics, 50, 353-371.

Del Pezzo, E., Bianco, F., Giampiccolo, E., Tusa, G., and Tuve, T. (2015). A Reappraisal of Seismic Q Evaluated at Mt. Etna Volcano. Receipt for the Application to Risk Analysis, Journal of Seismology, 19(1), 105-119, doi:10.1007/s10950-014-9453-0.

Di Stefano, R., Kissling, E., Chiarabba, C., Amato, A., and Giardini, D. (2009). Shallow subduction beneath Italy: Three-dimensional images of the Adriatic European Tyrrhenian lithosphere system based on high-quality P wave arrival times, Journal of Geophysical Research: Solid Earth (1978-2012), 114(B5).

Díaz-Moreno, A., Ibáñez, J.M., De Angelis, S., GarcíaYeguas, A., Prudencio, J., Morales, J., Tuvè, T., and García, L. (2015). Seismic hydraulic fracture migration originated by successive deep magma pulses: The 2011-2013 seismic series associated to the volcanic activity of El Hierro Island, Journal of Geophysical Research: Solid Earth, 120(11), 7749-7770.

Díaz-Moreno, A., Koulakov, I., García-Yeguas, A., Jakovlev, A., Barberi, G., Cocina, O., Zuccarello, L., Scarfi, L., Patanè, D., Álvarez, I., García, L., Benítez, C., Prudencio, J., and Ibáñez, J.M. (2016). PARTOS - Passive and Active Ray TOmography Software: description and preliminary analysis using TOMOETNA experiment's dataset, Annals of Geophysics, 59(4), S0435, doi:10.4401/ag-7088.

Doglioni, C., Innocenti, F., and Mariotti, G. (2001). Why Mt. Etna?, Terra Nova, 13(1), 25-31.

Dvorak, J.J., and Dzurisin, D. (1997). Volcano geodesy:
The search for magma reservoirs and the formation of eruptive vents, Reviews of Geophysics, 35(3), 343-384.

Dzurisin, D. (2006). Volcano deformation: new geodetic monitoring techniques, Springer Science and Business Media.

Fialko, Y., Khazan, Y., and Simons, M. (2001). Deformation due to a pressurized horizontal circular crack in an elastic half-space, with applications to volcano geodesy, Geophysical Journal International, 146(1), 181-190.

Firetto Carlino, M., Zgur, F., Bruno, P.P.G., Coltelli, M., Sormani, L., Cavallaro, D., Ibáñez, J.M., and Patanè, D. (2016). Acquisition and preliminary analysis of multi-channel seismic reflection data, acquired during the oceanographic cruises of the TOMO-ETNA experiment, Annals of Geophysics, 59(4), S0430, doi:10.4401/ag-7083.

Furuya, M., Okubo, S., Sun, W., Tanaka, Y., Oikawa, J., Watanabe, H., and Maekawa, T. (2003). Spatiotemporal gravity changes at Miyakejima Volcano, Japan: Caldera collapse, explosive eruptions and magma movement, Journal of Geophysical Research: Solid Earth (1978-2012), 108(B4).

García-Yeguas, A., Koulakov, I., Ibáñez, J.M., and Rietbrock, A. (2012). First high resolution P wave velocity structure beneath Tenerife Island (Canary Islands, Spain), Journal of Geophysical Research, 117, doi:10. 1029/2011JB008970.

García-Yeguas, A., Ibáñez, J.M., Koulakov, I., Jakovlev, A., Romero-Ruiz, M.C., and Prudencio, J. (2014). Seismic tomography model reveals mantle magma sources of recent volcanic activity at El Hierro Island (Canary Islands, Spain), Geophysical Journal International, 199(3), 1739-1750.

García, L., Álvarez, I., Benítez, C., Titos, M., Bueno, Á., Mota, S., de la Torre, Á., Segura, J.C., Alguacil, G., Díaz-Moreno, A., Prudencio, J., García-Yeguas, A., Ibáñez, J.M., Zuccarello, L., Cocina, O., and Patanè, D. (2016). Advances on the automatic estimation of the P-wave onset time, Annals of Geophysics, 59(4), S0434, doi:10.4401/ag-7087.

Giampiccolo, E., D’Amico, S., Patanè, D., and Gresta, S. (2007). Attenuation and source parameters of shallow microearthquakes at Mt. Etna volcano, Italy, Bulletin of the Seismological Society of America, 97(1B), 184-197.

Gillot, P.Y., Kieffer, G., and Romano, R. (1994). The evolution of Mount Etna in the light of potassiumargon dating, Acta Vulcanologica, 5, 81-87.

Gutiérrez, L., Ibáñez, J., Cortés, G., Ramírez, J., Benítez, C., Tenorio, V., and Isaac, Á. (2009). Volcano-seismic signal detection and classification processing 
using hidden Markov models. Application to San Cristóbal volcano, Nicaragua, In: Geoscience and Remote Sensing Symposium, 2009 IEEE International, IGARSS 2009 (Vol. 4, pp. IV-522).

Hirn, A., Nercessian, A., Sapin, M., Ferrucci, F., and Wittlinger, G. (1991). Seismic heterogeneity of Mt. Etna: structure and activity, Geophysical Journal International, 105(1), 139-153.

Ibáñez, J.M., Rietbock, A., and García-Yeguas, A. (2008). Imaging an active volcano edifice at Tenerife Island, Spain, Eos, Transactions American Geophysical Union, 89(32), 289-290.

Ibáñez, J.M., Benítez, C., Gutiérrez, L.A., Cortés, G., García-Yeguas, A., and Alguacil, G. (2009). The classification of seismo-volcanic signals using Hidden Markov Models as applied to the Stromboli and Etna volcanoes, Journal of Volcanology and Geothermal Research, 187(3), 218-226.

Ibáñez, J.M., et al. (2016). TOMO-ETNA experiment at Etna volcano: activities on land, Annals of Geophysics, 59(4), S0427, doi:10.4401/ag-7080.

Johnston, M.J.S. (1997). Review of electric and magnetic fields accompanying seismic and volcanic activity, Surveys in Geophysics, 18(5), 441-476.

Kauahikaua, J., Hildenbrand, T., and Webring, M. (2000). Deep magmatic structures of Hawaiian volcanoes, imaged by three-dimensional gravity models, Geology, 28(10), 883-886.

Koulakov, I., Gordeev, E.I., Dobretsov, N.L., Vernikovsky, V.A., Senyukov, S., Jakovlev, A., and Jaxybulatov, K. (2013). Rapid changes in magma storage beneath the Klyuchevskoy group of volcanoes inferred from time-dependent seismic tomography, Journal of Volcanology and Geothermal Research, 263, 75-91.

La Rocca, M., Petrosino, S., Saccorotti, G., Simini, M., Ibáñez, J.M., Almendros, J., and Del Pezzo, E. (2000). Location of the source and and shallow velocity model deduced by the explosion queakes recorded by two seismic antennas at Stromboli volcano, Physics and Chemistry of the Earth, 25, 731-736.

La Rocca, M., Saccorotti, G., Del Pezzo, E., and Ibáñez, J. (2004). Probabilistic source location of Explosion Quakes at Stromboli volcano estimated with double array data, Journal of Volcanology and Geothermal Research, 131, 123-142.

Laigle, M., Hirn, A., Sapin, M., Lepine, J.C., Diaz, J., Gallart, J., and Nicolich, R. (2000). Mount Etna dense array local earthquake $P$ and $S$ tomography and implications for volcanic plumbing, Journal of Geophysical Research-Solid Earth, 105, 21633-21646.

Lentini, F., Carbone, S., and Guarnieri, P. (2006). Collisional and postcollisional tectonics of the Apen-
ninic-Maghrebian orogen (southern Italy), Geological Society of America Special Papers, 409, 57-81.

Lodge, A., Nippress, S.E.J., Rietbrock, A., García-Yeguas, A., and Ibáñez, J.M. (2012). Evidence for magmatic underplating and magma chambers beneath the $\mathrm{Ca}$ nary Islands derived using teleseismic receiver functions, Physics of the Earth and Planetary Interiors, 212/213, 44-54.

Mantovani, E., Albarello, D., Tamburelli, C., and Babbucci, D. (1996). Evolution of the Tyrrhenian basin and surrounding regions as a result of the AfricaEurasia convergence, Journal of Geodynamics, 21(1), 35-72.

Marsella, E., et al. (2007) The Stromboli geophysical experiment. Preliminary report on wide angle refraction seismics and morphobathymetry of Stromboli island (Southern Tyrrhenian sea, Italy) based on integrated offshore-onshore data acquisition, ISMARCNR Bologna Technical Report No.102.

Martínez-Arévalo, C., Bianco, F., Ibáñez, J.M., and Del Pezzo, E. (2003). Shallow seismic attenuation and shear-wave splitting in the short period range of Deception Island volcano (Antarctica), Journal of Volcanology and Geothermal Research, 128(1), 89-113.

Martínez Arévalo, C., Patanè, D., Rietbrock, A., and Ibáñez, J.M. (2005). The intrusive process leading to the Mt. Etna 2001 flank eruption: Constraints from 3D attenuation tomography, Geophysical Research Letters, 32, doi:10.1029/2005GL023736.

Martínez Arévalo, C., Musumeci, C., and Patanè, D. (2009). Evidence of a partial melt zone beneath Stromboli volcano (Italy) from inversion of teleseismic receiver functions, Terra Nova, 21(5), 386-392.

Matsubara, M., Obara, K., and Kasahara, K. (2008). Three-dimensional P-and S-wave velocity structures beneath the Japan Islands obtained by high-density seismic stations by seismic tomography, Tectonophysics, 454(1), 86-103.

Michel, S., and Zlotnicki, J. (1998). Self-potential and magnetic surveying of La Fournaise volcano (Réunion Island): Correlations with faulting, fluid circulation, and eruption, Journal of Geophysical Research: Solid Earth (1978-2012), 103(B8), 1784517857.

Milano, G., Vilardo, G., and Luongo, G. (1994). Continental collision and basin opening in Southern Italy: a new plate subduction in the Tyrrhenian Sea?, Tectonophysics, 230(3/4), 249-264.

Monaco, C., Catalano, S., Cocina, O., De Guidi, G., Ferlito, C., Gresta, S., Musumeci, C., and Tortorici, L. (2005). Tectonic control on the eruptive dynamics at Mt. Etna Volcano (Sicily) during the 2001 and 2002-2003 eruptions, Journal of Volcanology and 
Geothermal Research, 144(1), 211-233.

Monaco, C., Ibáñez, J.M., Carrión, F., and Tringali, L.M. (2016). Cetacean behavioural responses to noise exposure generated by seismic surveys: how to mitigate better?, Annals of Geophysics, 59(4), S0436, doi:10.4401/ ag-7089.

Nicolich, R., Laigle, M., Hirn, A., Cernobori, L., Gallart, J. (2000). Crustal structure of the Ionian margin of Sicily: Etna volcano in the frame of regional evolution, Tectonophysics, 329, 121-139.

O’Brien, G.S., Lokmer, I., De Barros, L., Bean, C.J., Saccorotti, G., Metaxian, J.P., and Patanè, D. (2011). Time reverse location of seismic long-period events recorded on Mt. Etna, Geophysical Journal International, 184(1), 452-462.

Onizawa, S., Oshima, H., Aoyama, H., Mori, H., Maekawa, T., Suzuki, A., Tsutsui, T., Matsuwo, N., Oikawa, J., Ohminato, T., Yamamoto, K., Mori, T., Taira, T., Miyamachi, H., and Okada, H. (2007). Pwave velocity structure of Usu volcano: Implications of structural controls on magma movements and eruption locations, Journal of Volcanology and Geothermal Research, 160, 175-194.

Palo, M., Ibáñez, J.M., Cisneros, M., Bretón, M., Del Pezzo, E., Ocaña, E., and Posadas, A. (2009). Analysis of the wavefield properties of the volcanic explosions at Volcán de Colima, México: insight of the source mechanism, Geophysical Journal International, 177, 1383-1398.

Patanè, D., Ferrari, F., and Ferrucci, F. (1999). First application of ASDP software: a case study at Mt. Etna volcano and in the Acri region (Southern Italy), Physics of the Earth and Planetary Interiors, 113(1), 75-88.

Patanè, D., Chiarabba, C., Cocina, O., De Gori, P., Moretti, M., and Boschi, E. (2002). Tomographic images and 3D earthquake locations of the seismic swarm preceding the $2001 \mathrm{Mt}$. Etna eruption: Evidence for a dyke intrusion, Geophysical Research Letters, 29(10), doi:10.1029/2001GL014391.

Patanè, D., Cocina, O., Falsaperla, S., Privitera, E., and Spampinato, S. (2004). Mt. Etna volcano: a seismological framework, In: Bonaccorso, A., Calvari, S., Coltelli, M., Del Negro, C., and Falsaperla, S. (eds.), Mt. Etna: Volcano Laboratory, AGU (Geophysical Monograph Series, no. 143), 147-165, doi:10.1029/ 143 GM04.

Patanè, D., Mattia, M., and Aloisi, M. (2005). Shallow intrusive processes during 2002-2004 and current volcanic activity on Mt. Etna, Geophysical Research Letters, 32(6).

Patanè, D., Barberi, G., Cocina, O., De Gori, P., and Chiarabba, C. (2006). Time-resolved seismic to- mography detects magma intrusions at Mount Etna, Science, 313, 821-823.

Patanè, D., Aliotta, M., Cannata, A., Cassisi, C., Coltelli, M., Di Grazia, G., Montalto, P., and Zuccarello, L. (2011), Interplay between Tectonics and Mount Etna’s Volcanism: Insights into the Geometry of the Plumbing System, In: Uri Schattner (ed.), New Frontiers in Tectonic Research-At the Midst of Plate Convergence, 73-104; ISBN 978-953-307-594-5.

Patanè, D., Aiuppa, A., Aloisi, M., Behncke, B., Cannata, A., Coltelli, M., Di Grazia, G., Gambino, S., Gurrieri, S., Mattia, M., and Salerno, G. (2013). Insights into magma and fluid transfer at Mount Etna by a multiparametric approach: a model of the events leading to the 2011 eruptive cycle, Journal of Geophysical Research: Solid Earth, 118(7), 3519-3539.

Paulatto, M., Annen, C., Henstock, T.J., Kiddle, E., Minshull, T.A., Sparks, R.S.J., and Voight, B. (2012). Magma chamber properties from integrated seismic tomography and thermal modeling at Montserrat, Geochemistry, Geophysics, Geosystems, 13(1).

Petrosino, S., Cusano, P., La Rocca, M., Galluzzo, D., Orozco-Rojas, J., Bretón, M., Ibáñez, J.M., and Del Pezzo, E. (2011). Source location of long period and low frequency seismicity at Colima volcano, Bulletin of Volcanology, 73, 887-898, doi:10.1007/s004 45-011-0447-2.

Prudencio, J., Del Pezzo, E., García-Yeguas, A., and Ibáñez, J.M. (2013a). Spatial distribution of intrinsic and scattering seismic attenuation in active volcanic islands - I: Model and the case of Tenerife Island, Geophysical Journal International, 195(3), 19421956, doi:10.1093/ gji / ggt361.

Prudencio, J., Ibáñez, J.M., García-Yeguas, A., Del Pezzo, E., and Posadas, A.M. (2013b). Spatial distribution of intrinsic and scattering seismic attenuation in active volcanic islands - II: Deception Island images, Geophysical Journal International, 195(3), 1957-1969, doi:10.1093 / gji/ggt360.

Prudencio, J., De Siena, L., Ibáñez, J.M., Del Pezzo, E., García-Yeguas, A., and Díaz-Moreno, A. (2015a). The 3D Attenuation Structure of Deception Island (Antarctica), Surveys in Geophysics, 36(3), 371-390.

Prudencio, J., Del Pezzo, E., Ibáñez, J.M., Giampiccolo, E., and Patanè, D. (2015b). Two-dimensional seismic attenuation images of Stromboli Island using active data, Geophysical Research Letters, 42(6), 1717-1724.

Prudencio, J., Ibáñez, J.M., Del Pezzo, E., Martí, J., García-Yeguas, A., and De Siena, L. (2015c). 3D Attenuation Tomography of the Volcanic Island of Tenerife (Canary Islands), Surveys in Geophysics, 36(5), 693-716. 
Rymer, H., and Brown, G.C. (1986). Gravity fields and the interpretation of volcanic structures: geological discrimination and temporal evolution, Journal of Volcanology and Geothermal Research, 27(3), 229254.

Saccorotti, G, Zuccarello, L., Del Pezzo, E., Ibáñez, J.M, and Gresta, S. (2004). Quantitative analysis of the tremor wavefiled at Etna volcano, Italy, Journal of Volcanology and Geothermal Research, 136, 223245.

Selvaggi, G., and Chiarabba, C. (1995). Seismicity and P-wave velocity image of the Southern Tyrrhenian subduction zone, Geophysical Journal International, 121(3), 818-826.

Shalev, E., Kenedi, C.L., Malin, P., Voight, V., Miller, V., Hidayat, D., Sparks, R.S.J., Minshull, T., Paulatto, M., Brown, L., and Mattioli, G. (2010). Three-dimensional seismic velocity tomography of Montserrat from the SEA-CALIPSO offshore/onshore experiment, Geophysival Research Letters, 37, doi:10.102 9/2010GL042498.

Soengkono, S. (1995). A magnetic model for deep plutonic bodies beneath the central Taupo Volcanic Zone, North Island, New Zealand, Journal of Volcanology and Geothermal Research, 68(1), 193-207.

Spilliaert, N., Allard, P., Métrich, N., and Sobolev, A.V. (2006). Melt inclusion record of the conditions of ascent, degassing, and extrusion of volatile-rich alkali basalt during the powerful 2002 flank eruption of Mount Etna (Italy), Journal of Geophysical Research: Solid Earth, 111(4), doi:10.1029/2005JB003 934.

Sturkell, E., Einarsson, P., Sigmundsson, F., Geirsson, H., Olafsson, H., Pedersen, R., de Zeeuw-van Dalfsen, E., Linde, A.T., Sacks, S.I., and Stefánsson, R. (2006). Volcano geodesy and magma dynamics in Iceland, Journal of Volcanology and Geothermal Research, 150(1), 14-34.

Torelli, L., Grasso, M., Mazzoldi, G., and Peis, D. (1998). Plio-Quaternary tectonic evolution and structure of the Catania foredeep, the northern Hyblean Plateau and the Ionian shelf (SE Sicily), Tectonophysics, 298(1), 209-221.

Ventura, G., Vilardo, G., Milano, G., and Pino, N.A. (1999). Relationships among crustal structure, volcanism and strike-slip tectonics in the Lipari-Vulcano volcanic complex (Aeolian Islands, Southern Tyrrhenian Sea, Italy), Physics of the Earth and Planetary Interiors, 116(1), 31-52.

Villaseñor, A., Benz, H.M., Filippi, L., De Luca, G., Scarpa, R., Patanè, G., and Vinciguerra, S. (1998). Three-dimensional P-wave velocity structure of Mt. Etna, Italy, Geophysical Research Letters, 25(11),
1975-1978.

Voight, B., et al. (2014). The SEA-CALIPSO volcano imaging experiment at Montserrat: plans, campaigns at sea and on land, scientific results, and lessons learned, Geological Society, London, Memoirs, 39(1), 253289.

Westaway, R. (1993). Quaternary uplift of southern Italy, Journal of Geophysical Research: Solid Earth (1978-2012), 98(B12), 21741-21772.

Zandomeneghi, D., Almendros, J., Ibáñez, J.M., and Saccorotti, G. (2008). Seismic tomography of Central Sao Miguel, Azores, Physics of the Earth and Planetary Interiors, 167(1), 8-18.

Zandomeneghi, D., Barclay, A., Almendros, J., Ibáñez, J., and Wilcock, W.S.D. (2009). Crustal structure of Deception Island volcano from $\mathrm{P}$ wave seismic tomography: tectonic and volcanic implications, Journal of Geophysical Research, 114, doi:10.1029/2008 JB006119.

Zieger, T., Sens-Schönfelder, C., Ritter, J.R.R., Lühr, B.G., and Dahm, T. (2016). P-wave scattering and the distribution of heterogeneity around Etna volcano, Annals of Geophysics, 59(4), S0432, doi:10.4401/ag7085.

Zollo, A., Gasparini, P., Biella, G., Boschi, E., Capuano, P., De Franco, R., Dell'Aversana, P., De Matteis, R., De Natale, G., Iannaccone, G., Guerra, I., Le Meur, H., and Mirablie, L. (1998). An image of Mt. Vesuvius obtained by $2 \mathrm{D}$ seismic tomography, Journal of Volcanology and Geothermal Research, 82, 161-173.

Zuccarello, L., Burton, M.R., Saccorotti, G., Bean, C.J., and Patanè, D. (2013). The coupling between very long period seismic events, volcanic tremor, and degassing rates at Mount Etna volcano, Journal of Geophysical Research: Solid Earth, 118(9), 49104921.

Zuccarello, L., Paratore, M., La Rocca, M., Ferrari, F., Messina, A., Branca, S., Contrafatto, D., Galluzzo, D., Rapisarda, S., and García, L. (2016). Shallow velocity model in the area of Pozzo Pitarrone, Mt. Etna, from single station, array methods and borehole data, Annals of Geophysics, 59(4), S0433, doi:10.4401/ag-7086.

${ }^{\star}$ Corresponding author: Jesús M. Ibáñez,

Instituto Andaluz de Geofisica, Universidad de Granada, Granada, Spain; email: jibanez@ugr.es.

C 2016 by the Istituto Nazionale di Geofisica e Vulcanologia. All rights reserved. 


\section{Appendix A}

\section{Funding and associated research projects}

The TOMO-ETNA experiment was evolved between 2011 and 2014, and mainly integrates the European Union project "MEDiterranean SUpersite Volcanoes (MED-SUV)" efforts with the resources of the EU project "EUROFLEETS2". However other funding agencies from Italy, Spain, and Germany supported this experiment. In addition, the Italian Navy and Sicily's Regional Civil Protection Department actively participated in the experiment. This such a long time interval includes several negotiations with different research and civil agencies and the application of various additional research project and parallel aids, including economic, equipment and human additional support. Both main research projects (MED-SUV and EUROFLEETS2) will be specifically described in next sections. The number of associated projects and other negotiations is large, and a full description of then is reported in Section A3. Next we will mention some of these negotiations processes and support obtained from them.

\section{A1. MED-SUV project. The core project of the TOMO-}

\section{ETNA experiment}

The TOMO-ETNA experiment was conceived, planned and carried out in the framework of the EC-FP7 MEDiterranean Supersite Volcanoes (MED-SUV) project, which overarching objective was to apply the Supersite rationale to the Italian active volcanoes. The Supersite initiative born on 2007 at the conclusion of the 3rd International Geohazards workshop of GEO held in November 2007 in Frascati, Italy, with the aims "to stimulate an international and intergovernmental effort to monitor and study selected reference sites by establishing open access to relevant datasets according to Group Of Earth Observation (GEO) principles to foster the collaboration between all various partners and end-users" (Frascati declaration). Selected sites (Supersites) are areas prone to earthquake, volcano or other hazards and for which significant Earth observation and ground-based data sets are available. Thus, although not explicitly declared, Supersite initiative is intrinsically multiplatform being based on the use of data provided by research infrastructures belonging to space and Earth domains. On 2011 the European Commission promoted the application of the Supersite approach in Europe though a specific call; MED-SUV was one of the projects which positively responded to this call, focused their activities on Mt. Etna and Campi Flegrei/Vesuvius volcanoes. Since 2013 these two areas have been appointed as Permanent Supersites from the Scientific Advisory Committee (SAC) of GEO Geohazards Supersites and Natural Laboratories (GSNL), also considering the existence of MED-SUV project. In- deed, more than 3 million of people are exposed to potential volcanic hazards in a large region in the Mediterranean Sea, where these two volcanic areas are located. The wide range of styles and intensities of volcanic phenomena observed on these volcanoes, which can be assumed as archetypes of 'closed' and 'open conduit' volcano, together with the long-term multidisciplinary data sets give an exceptional opportunity to improve the understanding of a very wide spectrum of geohazards, as well as implementing a large variety of innovative models for investigating the volcanic processes.

The improvement of the knowledge of the Supersites and the sharing of the relevant data sets are two key principles of the Frascati declaration, which are the base for the enhancement of the hazard assessment and the risk reduction. MED-SUV adopted these two principles in the work plan definition, by attempting to cope with the main gaps in the knowledge in both areas and to improve the sharing of the data relevant to the two Supersites (either provided by the ground-based monitoring institutions, space agencies or collected during the project). The project proposes the development and implementation of a state-of-the-art infrastructure for the volcanic risk management life-cycle, from the observation to people preparedness. Thus, MED-SUV project offers the opportunity to operate in natural laboratories by using cutting-edges technologies and carrying out in-field and laboratories experiments.

Indisputably Mt. Etna and Campi Flegrei/Vesuvius are among the most well-known volcanoes worldwide. However, one of the most relevant gaps in the knowledge of Mt. Etna consisted in the relatively poor information concerning the deep structure of this volcano. Indeed, this inadequacy in the knowledge of the crust limits the capability of the models to investigate the dynamic of this volcano, despite through the last decades the computational capacity improved dramatically and many sophisticated numerical modelling approaches have been implemented.

A2. EUROFLEETS2. TOMO-ETNA experiment and marine implications

EUROFLEETS2 "New operational steps towards an alliance of European research fleets" (March 1, 2013, to February 28, 2017, Grant Agreement No. 312762) is a project funded in the frame of the 7th Framework Programme of the European Commission. The project is the extension and expansion of the first initiative, EUROFLEETS "Towards an alliance of European research fleets" (September 1, 2009, to August 31, 2013, Grant Agreement No. 228344). Both projects were granted under the funding schemes of research infrastructures and respectively a combination of Collabo- 
rative Project and Coordination and Support Actions for Integrating Activities.

Research vessels (R/Vs) and their embarked equipment are crucial infrastructures necessary for marine sciences. They provide sea access to the whole community of researchers, enable all kinds of observations, in-situ measurements, sampling and mapping, and are necessary to maintain deep sea observatories. Over the years, the missions assigned to R/Vs became more complex and technically sophisticated. This encourages national marine institutions to increase their coordination and collaboration, and to share their facilities in order to optimize the cost in operating their marine infrastructures and to efficiently meet the scientific ever increasing demands.

By bringing together European research fleet owners and operators, EUROFLEETS2 (http: / / www.euro fleets.eu) contributes to enhance operational coordination between $\mathrm{R} / \mathrm{Vs}$ and associated equipment. It has the aim of developing a new pan-European distributed infrastructure with common strategic vision and coordinated access to R/Vs and associated equipment, in order to facilitate the access to these rare floating laboratories and maximize their contribution to the scientific knowledge.

Through operational initiatives such as regional virtual fleets or the development of common tools or methodologies, this project promotes more inter-operable and cost-effective European research fleets for sustainable management of regional seas and oceans. EUROFLEETS2 aims also to develop the impact of research infrastructures on innovation by establishing links with industry and fostering the involvement of the industrial sector on specific activities.

EUROFLEETS2 involves multi-disciplinary expertise from thirty-one marine institutes, universities, foundations and small and medium enterprises (SMEs) from twenty member states of the European Union, four associated countries, and one overseas country and territory. The project has ambitious objectives and the 31-member consortium works together in three structured and complementary research activities:

i) the transnational access (TNA), as core activity of the project, to coordinate access to European R/Vs and associated equipment for all European scientists and their partners;

ii) the joint research activity (JRA) for joint development of common equipment or software;

iii) the networking activity (NA) with a range of actions for an enhanced coordination of European research fleets including the polar components. This activity includes also the opening of TNA calls and the evaluation of submitted proposals by a European panel of experts. Specific tasks are undertaken as well for the training of young marine scientists.

Within the innovative EUROFLEETS2 TNA activity, three different types of calls were opened: $i$ ) three calls offering access to 22 European R/Vs operating in targeted maritime regions (call 1 for polar and sub-polar regions, call 2 for North Atlantic and North Sea, call 3 for Mediterranean Sea, Black Sea and Red Sea), ii) one "Embarked Equipment" call aiming to deploy pieces of equipment from their non-usual R/Vs or underwater vehicles, so contributing to higher inter-operability within European research fleets, and iii) the so called "Super-Integration" call in which the MEDSUV.ISES proposal was selected for funding.

With the "Super-Integration" call, EUROFLEETS2 wanted to further develop its integrating actions by proposing a multi-platform experiment as an innovative way of integrating European and international infrastructures. Such multi-platform experiments are very rare as they require a high level of anticipation and coordination and the objective was to allow the realization of a single multinational, large-scale scientific project able to attract international scientific leaders and non-traditional end users on board European R/Vs.

To achieve this, an expression of interest was opened very early in the project to allow potential candidates to check if their proposals were fitting with the "Super-Integration philosophy", and in that case, to check that EUROFLEETS2 could cover their needs. A dedicated unique call for proposals was launched afterwards, but very early in the project's life, to seek a scientific project which needed to mobilize a combination of EUROFLEETS2 TNA vessels, nationally funded R/Vs, together with other appropriate scientific tools like research planes or shore infrastructures proposed with their own EC or national funding. This call sought to identify a truly cross cutting proposal, able to prove its scientific excellence and to mobilize private and public funding structures on top of EUROFLEETS2 EC funding. High impact proposals with a significant cross cutting theme could seek to develop a multi-annual programme focused on one European location or develop a proposal which requires the deployment of several vessels and platforms with their associated equipment to a number of locations with a common theme.

The MEDSUV.ISES project was successfully selected for funding among a total of four scientific proposals submitted within the "Super-Integration" call. The support brought by EUROFLEETS2 to the TOMOETNA experiment of the MEDSUV project represented a total of 25 days of ship-time in 2014 on board the Spanish R/V "Sarmiento de Gamboa" and the Greek R/V "Aegaeo". 
A3. Additional research projects and parallel negotiations

In this section we detail additional research projects that have supported the TOMO-ETNA experiment and other parallel negotiations focused in the acquisition of human and material resources.

(a) Spanish COCSABO project. In order to use the Spanish oceanographic vessel "Sarmiento de Gamboa" the UGR team leaders by Jesús Ibáñez applied for a project named MED-SUV (COC-DI-2011-08) in November of 2011. The proposal was applied to La Comisión de Coordinación y Seguimiento de las Actividades de los Buques Oceanográficos (COCSABO) belonging to La Secretaría General de Ciencia y Tecnología del Ministerio de Economía y Competitividad of the Spanish government. The proposal was approved in January 2014 and allowed to program 25 days of activities of the vessel "Sarmiento de Gamboa" (CSIC) for the summer of 2014. It is important to note that the negotiations of this applications started before that the core project MEDSUV were approved and granted.

(b) European project EUROFLEETS2. In order to complement the use of the Spanish vessel "Sarmiento de Gamboa" and to include other additional oceanographic vessels, the consortium composed by the INGV, Section of Catania (hereinafter: INGV-Catania) leaded by G. Puglisi and D. Patanè and the UGR partner leaded by J.M. Ibáñez applied for the project "MED-SUV. Integration of on-shore and off-shore passive and active Seismic Experiments in South Italy" (MED-SUV.ISES) within the EUROFLEETS2 "Super-Integration" call opened in June of 2013 (a more detailed description of EUROFLEETS2 is provided in the next section). Successfully evaluated by a European panel of experts, the scientific proposal was selected for funding in April 2014, permitting to complement the activities programmed by the "Sarmiento de Gamboa" and to include new geophysical activities using the Greek research vessel "Aegaeo" in November of 2014. Once the use of the oceanographic vessels was secured by these two projects, the final dates of the experiment were fixed definitively to start at the end of June of 2014.

(c) German project TOMO-ETNA (Seismic TOMOgraphy of ETNA volcano and Eolian Islands, Italy, using active and passive seismic data). In order to obtain and homogeneous set of portable seismic stations, a proposal was submitted to the German Geophysical Instrument Pool Potsdam (GIPP). This pool belongs to the Helmholtz-Centre Potsdam-GFZ German Research Centre of Germany. In June 2013 the consortium comprising the GFZ-Postdam, INGV-Catania and the UGR prepared a proposal for the use of instruments that was submitted in August 2013. The leaders of this project were B.-G. Lühr and T. Dahm from GFZ,
G. Puglisi and D. Patanè from INGV-Catania and J.M. Ibáñez from UGR. In February 2014 we obtained the final confirmation of the availability of 100 seismic stations, including 80 short period seismic stations and 20 BB, to be used in the period June-November 2014.

(d) Negotiation with Dipartimento Regionale della Protezione Civile, Regione Siciliana, for the use of their different resources in the TOMO-ETNA experiment. The INGV-Catania leader $\mathrm{D}$. Patanè prepared a preliminary agreement with the Department that was signed. In this first document additional grants for the expected onland chemical explosions were included. The working period of this process was November 2013 to June 2014. Due to economical restrictions the final support for the performing of chemical explosions on land was eliminated in July 2014, just when the experiment started, and these activities were cancelled in the last minute.

(e) Agreement with the Observatory of Gibilmanna, run by the Centro Nazionale Terremoti (the INGV National Earthquake Center; hereinafter: INGV-CNT), to use Italian OBS in the experiment. The INGV-Catania leader $\mathrm{D}$. Patanè requested the use of at least 12-14 OBS to this institution. This agreement was closed and they prepared the instrument to be deployed in the TOMO-ETNA experiment, three of them remained deployed for around 6 months and were recovered by the Greek vessel "Aegaeo". The working period of this process was November 2013 to June 2014.

(f) Negotiation with the Unidad de Tecnología Marina - CSIC in Barcelona (Spain) to use Spanish OBS in the experiment. The UGR leader J.M. Ibáñez and INGVCatania leader $\mathrm{D}$. Patanè requested the use of at least 12-15 OBS to this institution. This agreement was confirmed and the CSIC team prepared the instruments that were deployed in the TOMO-ETNA experiment. The working period of this process was November 2013 to June 2014.

(g) Negotiation with the Italian Navy (Italian Navy General Staff and Command in Chief of the Fleet) for the use of a hydrographic vessel. In order to deploy the Italian OBS and to perform high definition bathymetry and magnetic profiles, the INGV-Catania leader D. Patanè and M. Coltelli and the INGV-Roma 2 (Porto Venere) leader C. Carmisciano applied for an agreement between MED-SUV and the Italian Navy. In this agreement allowed us to use, free of charges, the H/V "Galatea" for a period of 10 days starting on June 25, 2014.

(h) Negotiation with the Italian Navy Command of Sicily in Augusta, for the use of a logistic support ship and the use of a military dock during the experiment. The INGV-Catania leader D. Patanè and M. Coltelli, and UGR leader J.M. Ibáñez negotiated with this institution the use of a support ship that would have helped the "Sarmiento 
de Gamboa" during the seismic reflection experiment with the $3 \mathrm{~km}$ long streamer. Additionally, in order to save cost, a negotiation to use the military dock for ship berthing was opened. The working period of this process was October 2013 to June 2014.

(i) Bilateral negotiation between Spanish, Greek and Italian Foreign Offices to request authorization of marine scientific work in the economic exclusive zones of Italy. The UGR leader J.M. Ibáñez with the collaboration of $\mathrm{D}$. Patanè and $\mathrm{M}$. Coltelli from INGV-Catania prepared an official document and memorandum to obtain this authorization. This negotiation implied the participation of the Spanish embassy in Rome. The working period of this process was March 2014 to October 2014.

(j) Negotiation with OGS, Trieste (Italy). M. Coltelli and D. Patanè from INGV-Catania established an agreement with the OGS institution in order to have access to multichannel seismic instruments to be deployed from the "Aegaeo" vessel. These instruments were: two GI guns in linear array and its air compressor arranged in TEU-20 container, and a 96 channels, $300 \mathrm{~m}$ long digital streamer. This negotiation started in September 2014, including a further negotiation with Italian Coast Guard of Messina to obtain the local authorization to use air-gun without damage marine mammals.

\section{Appendix B}

\section{List of the TOMO-ETNA working group}

Here it is the list of people who currently form the working group with a short description of their contribution to the experiment.

\section{UGR, Spain:}

General coordinator of the experiment: Jesús M. Ibáñez Spanish marine coordinator: Francisco Carrión

Onland activities coordinator: Alejandro Díaz-Moreno; Janire Prudencio

Onland seismic stations: Rafael Abreu; Gerardo Alguacil; Isaac Álvarez; Carolina Aranda; Carmen Benítez; Luisa Buontempo; Mercedes Feriche; Luz García; Daniel García; Cristina González; José Benito Martín; José Morales; Inmaculada Serrano; Manuel Titos; Lucia Urbano Onboard marine activities: Judit González Santana; Nuria Gutiérrez Luna; Ana Isabel Lozano Martínez; Diego Martín Jiménez; José Manuel Muñoz Hermosilla; Mayte Pedrosa; Elsa María Alfonso Sánchez; Teresa Teixidó.

INGV, Osservatorio Etneo, Catania, Italy: General coordinator: Domenico Patanè Italian marine coordinator: Mauro Coltelli MED-SUV coordinator: Giuseppe Puglisi Onland activities coordinator: Ornella Cocina; Luciano

\section{Zuccarello}

Onland seismic stations: Giampiero Aiesi; Raffaele Azzaro; Graziella Barberi; Massimo Cantarero; Pasqualino Cappuccio; Danilo Contrafatto; Graziano La Rocca; Sergio Di Prima; Susanna Falsaperla; Elisabetta Giampiccolo; Carla Musumeci; Daniele Pellegrino; Mario Pulvirenti; Salvatore Rapisarda; Marco Sassano; Luciano Scarfi; Luciano Scuderi; Antonino Sicali; Giuseppina Tusa; Tiziana Tuvè

Onboard marine activities: Eloisa Claude; Marco Firetto Carlino; Salvatore Rapisarda.

INGV, Osservatorio Vesuviano, Naples, Italy: Coordinator: Francesca Bianco Scientific coordinator: Edoardo Del Pezzo Onland seismic stations: Stefano Fiore; Danilo Galluzzo; Mario La Rocca; Mariantonietta Longobardi; Luciano Nocerino; Solange Scognamiglio.

INGV, Centro Nazionale Terremoti, Rome, Italy: Italian OBS coordinator: Giuseppe D’Anna Marine and onland activities: Fabio Criscuoli; Antonino D’Alessandro; Roberto D’Anna; Pasquale De Gori; Gioacchino Fertitta; Lucian Giovani; Giuseppe Passafiume; Marcello Silvestri; Stefano Speciale.

INGV, Sezione Roma 2, Rome, Italy: Project - Italian Navy coordinator: Cosmo Carmisciano Marine and onland activities: Carla Bottari; Pier Paolo G. Bruno; Luca Cocchi; Filippo Muccini.

INGV, Sezione di Bologna, Bologna, Italy: Onland seismic stations: Simone Salimbeni.

OGS, Trieste, Italy: Marine activities coordinator: Fabrizio Zgur Marine activities: Lorenzo Facchin; Giampaolo Visnovic; Lorenzo Sormani; Diego Cotterle; Rita Blanos; Paolo Mansutti.

GFZ, Potsdam, Germany:

Portable seismic stations coordinators: Birger-Gottfried Lühr; Torsten Dahm.

Univ. Catania, Italy:

Marine activities: Fabrizio Cultrera; Danilo Cavallaro; Clara Monaco.

Univ. La Coruña, Spain: Onland seismic stations: Pedro Gea.

Univ. Cádiz, Spain:

Onland seismic stations: Araceli García-Yeguas. 
Univ. Jaén, Spain:

Onland seismic stations: Alfonso Ontiveros.

Univ. La Laguna, Spain:

Onland seismic stations: Enrique Coello; María Cordero; Cayetano Guillén; Carmen Romero.

Univ. College of Dublin, Ireland: Onland seismic stations: Hannah McCann.

Univ. Colima, Mexico:

Onland seismic stations: Mauricio Bretón.

Berckley Seismological Lab., USA: Scientific coordinator: Margaret Hellweg Onland seismic stations: Sierra Boyd.

IPGG SB, Novrosibirsk, Russia: Software coordinator: Ivan Koulaikov Onland seismic stations: Sergey Abramenkov.

\section{Appendix C}

\section{International collaborations}

The objective of TOMO-ETNA experiment will contribute to part of the EU Project MED-SUV objectives and therefore is integrated by a large set of members associated to this FP7 EU project. Additionally, other institutions that have been collaborated in similar previous experiments have been integrated to the present one.

The MED-SUV consortium that support this project is composed by 21 research institutions from Italy, Germany, UK, France, Spain, Portugal and Malta, and 4 private companies from Italy and UK. As partners of the present experiment we have researcher from the following institutions: INGV, Catania, Rome, Porto Venere, Bologna and Naples (Italy); Universidad de GranadaUGR (Spain); GFZ-Potsdam (Germany); OGS, Trieste (Italy); University of California-Berkeley-BSL (USA); University College of Dublin - UCD (Ireland); Universidad de Colima (Mexico); Universidad de La Laguna (Spain); Universidad de Jaén (Spain); Universidad de Cádiz (Spain); Università di Catania (Italy); CSIC Spain; and Institute of Petroleum, Geology and Geophysics-IPGG (Russia).

The role, in term of responsibilities, of the different partners of the project was:

- UGR was the main coordinator of the experiment, both marine and on-land, and is the scientific coordinator of the future data analysis.

- INGV-Catania was the general coordinator of MED-SUV project and was be the connecting link between this project and the other projects. Additionally, the on-land and part of the offshore operations were coordinated by this partner.

- GFZ was the responsible of the portable seismic network.

- IPGG is the responsible of the elaboration of joint inversion software that integrates passive and active seismic data in both environments to obtain the tomographic images.

In order to recognize the work performed by the several researchers involved in the organization, materialization and future analysis of the data, TOMOETNA working group was created. The list of the names of the persons involved in this working group was enlarged with time according with new contributions and contributors. This list will be used as reference of the authors for the different scientific products that will be produced in the future such as presentation in international conferences. In Appendix B we present the full list of this working group.

\section{Appendix D}

\section{Data management and control}

Such a complex experiment like TOMO-ETNA has generated a big amount of data in both terrestrial and marine environments. The data base can be divided according to the type of instruments and data recording systems but also according to the environment, marine or terrestrial. The division of the data base was done as follow: Short Period Portable Seismic Stations; Portable Broadband Stations; OBS Stations, Spanish and Italian; INGV Permanent Seismic Network; Seismic Streamer Data; other Marine Data. In total around 6.5 $\mathrm{Tb}$ of data in the raw format have been collected divided as follow: $1.5 \mathrm{~Tb}$ for portable short-period and broadband seismic stations; $1 \mathrm{~Tb}$ for the permanent seismic network of the INGV; $0.5 \mathrm{~Tb}$ for the OBS; $3 \mathrm{~Tb}$ for marine streamer data in both legs ("Sarmiento de Gamboa" and "Aegaeo" vessels); $0.5 \mathrm{~Tb}$ for the rest of geophysical and marine data, such as magnetic, bathymetric or robot images, among others. The policy of the data is indicated by following the policy of the MED-SUV Consortium. The use of the data is currently restricted to the MED-SUV consortium, until the end of the project. Data set will be available at the MED-SUV portal. After the end of the project, the data policy has to follow the EUROFLEET rules, which foresee an open access. Access rules should be still defined. In the follow we describe were physically these data are storage and in the future available.

\subsection{Short period portable seismic stations}

The project has several copies of the short period portable seismic station data and they are stored in 
Catania, Naples, Potsdam and Granada in the raw data format. There are some teams that have converted data formats to miniseed and SAC format in Granada, Catania and Potsdam.

\subsection{Portable broadband stations}

Data of these stations have the same processing and storage policy that the short period stations.

\subsection{OBS data}

\subsubsection{Spanish OBS}

The original OBS data are in CSIC-UTM, Catania and Granada in the raw format. UGR transformed them into SEGY format. These data are distributed to Catania, Naples, and Potsdam.

\subsubsection{Italian OBS}

The original OBS data are stored in INGV-CNT in Gibilmanna. Later the data will be distributed to Catania, Naples Granada and Potsdam.

\subsection{INGV permanent seismic network}

A copy of the whole data from the period AprilNovember 2014 is available in Catania and Granada in $\mathrm{dmx}$ format. Naples can access to this copy via internal server. Researchers from UGR converted this format to SAC.

\subsection{Seismic streamer data}

A copy of data associated to the "Sarmiento de Gamboa" vessel is available in Catania and Granada (also in Barcelona as owner of the vessel). Data from "Aegaeo" campaign is available in Catania and Trieste (as owner of the streamer).

\subsection{Other marine data}

This data base was obtained during the experiment by "Sarmiento de Gamboa", "Galatea" and "Aegaeo" vessels, and it is composed by: bathymetry data, magnetic data and other measurements. This information is stored together with the MCS streamer data and is available in Catania and Granada. 